\title{
Symbolic action and constraint: the cultural logic of the 2017 UK General Election
}

\author{
Marcus Morgan ${ }^{1}$
}

Accepted: 8 January 2021 / Published online: 15 February 2021

(c) The Author(s), under exclusive licence to Springer Nature Limited part of Springer Nature 2021

\begin{abstract}
This paper examines the influence of both the agential and structural aspects of culture on the 2017 UK General Election. The empirical section of the paper is organised around three aspects of the Labour campaign narrative: its promise to provide a national 'alternative', its mobilisation of Corbyn as simultaneously an individual and an icon, and its use of rallies and social media as alternative stages from which to project its meanings. It identifies the material conditioning, coding and countercoding, narrativisation and counter-narrativisation of key events, issues, and figures, demonstrating how the substantive contestation of the campaign occurred within a consensual formal grammar that constrained symbolic action and often produced consequences unintended by cultural workers themselves. It, therefore, demonstrates how culture retained a relative autonomy in influencing meaning outcomes in part due to its formal semiotic logic. It introduces the notion of 'code-rerouting' to cultural sociology's stock of conceptual tools and highlights how failure to conform to the structuring norms of civil rituals, such as presenting oneself to public scrutiny during a campaign, or failure to project coherence between surface and depth, individual and icon, past and present, or between private and public can prove fatal to performative felicity.
\end{abstract}

Keywords 2017 General Election · Jeremy Corbyn · Labour Party · Cultural work · Civil sphere $\cdot$ Narrative

\section{Introduction}

'Good evening. I know nothing. We - the media, the pundits, the experts - know nothing. We simply didn't spot it'. So began veteran reporter Jon Snow's introduction to Channel 4 News on the day of the 2017 UK General Election results. The following day

Marcus Morgan

marcus.morgan@bristol.ac.uk

1 School of Sociology, Politics and International Studies (SPAIS), University of Bristol, 11 Priory Road, Clifton, Bristol BS8 1TU, UK 
Matthew Goodwin, Professor of Politics, ate his latest book on live TV, coming good on a promise that he would 'happily' do so if Labour under Corbyn polled over $38 \%$. During the days and weeks that followed, mea culpas from those charged with analysing British politics flooded in. Something remarkable had occurred during the election campaign that confounded both academic and journalistic commentators. When Theresa May triggered the snap election, her decision was initially met with 'almost universal agreement that she had made an astute if not brilliant call' (Bartle 2018, p. 161). A Political Studies Association survey conducted during the campaign of 335 leading academics, pollsters, and journalists (the vast majority, 280, were academics) predicted a $65 \%$ probability that the Conservatives would win a parliamentary majority greater than 100 seats (Fisher et al. 2017). ${ }^{1}$ In the event, in spite of the fact that the vast majority of the media, the parliamentary Labour Party, and-as revealed in a leaked dossier (Labour 2020)_the Labour Party bureaucracy itself, were aligned against the Corbyn leadership, the Conservatives ended up losing their majority and had to enlist the Northern Irish Democratic Unionist Party to prop up their government in a $£ 1$ billion deal.

Whatever had occurred during the short election period affected both Corbyn's and the Labour Party's support in striking ways (Fieldhouse and Prosser 2017). In terms of the former, Corbyn's average approval ratings moved from a net of -39 in April, to +1 in June. In terms of the latter, average polling for Labour when the election was called was around $25 \%$ (YouGov had them on 23\%), which was the worst polling before an election for the party since 1983. On election day, they won $40 \%$ of the vote (Figs. 1, 2), making Labour's first election gains since 1997. Whilst Labour did not win the election, they did rob the government of their majority and increas their vote share by a greater margin than at any other election since Clement Atlee's historic victory over Churchill in 1945. Since material conditions did not suddenly shift in any marked way during this short campaign period of under two months, this sudden upsurge in support demands alternative explanations.

The theoretical framing of this paper draws upon the 'strong program' in cultural sociology both in its attempt to 'anchor causality in proximate actors and agencies' (Alexander and Smith 2003, p. 14), as well as in its stress upon the importance of collective representations, audiences, means of symbolic production, power, and mise-enscène in helping shape whether performances are able to achieve successful 'fusion' (Alexander 2004). It also develops this framework in demonstrating the significance (in both senses of that word) of material factors in conditioning the election's course.

During the 8-week national drama of the UK General Election, many powerful actors made many important decisions that incontestably influenced the outcome of the event in important ways. Like any other work, cultural work does not occur spontaneously, but is undertaken by actors with intentions. For scaled-up national dramas, such agents often necessarily work in concert, via 'performance teams', which comprise sets 'of individuals whose intimate cooperation is required if a given definition of the situation is to be maintained' (Goffman [1990] 1959, p. 104; Morgan and Baert 2015; Morgan 2020a). A major element that constrained the efficacy of these performances were divisions, and on occasion even active sabotage, within the broader performance teams, seen especially in the Labour camp between

$1_{1}$ Research took place between 16th and 26th May; the election was called on 18th April. 


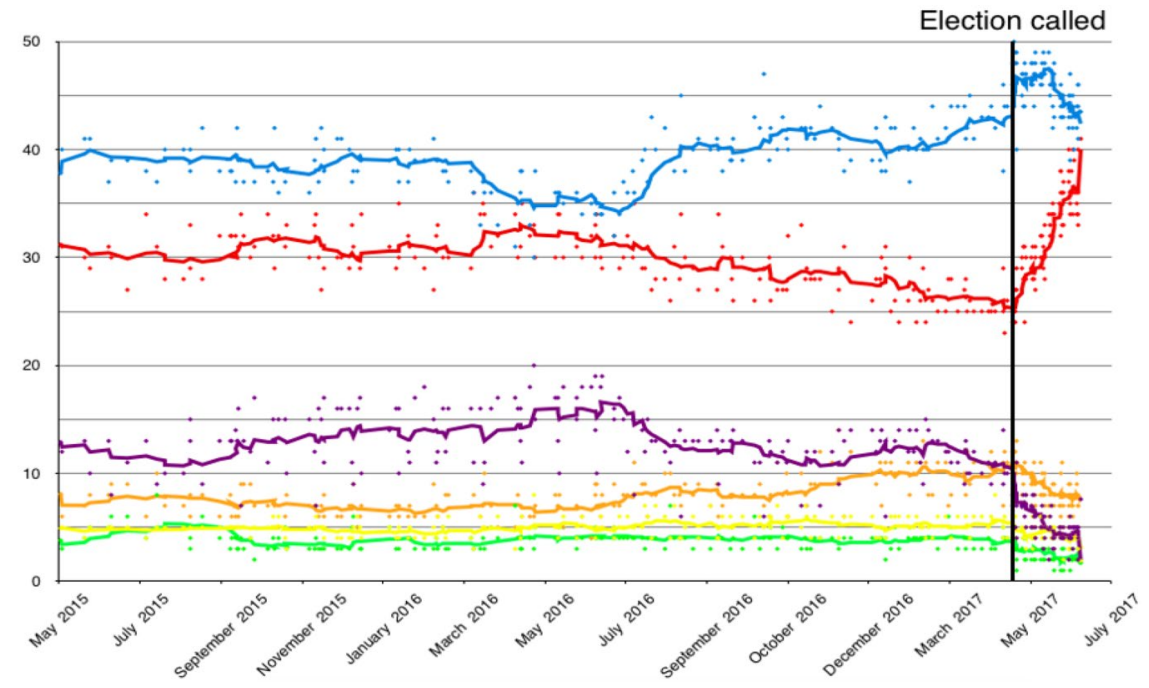

Graphed in order of descending polling scores in May, 2015: Blue - Conservative; Red - Labour; Purple - UKIP; Orange - Lib Dem; Yellow - SNP; Green - Green Party.

Source: Wikipedia (Creative Commons BY-SA 4.0)

Fig. 1 Average party polling May 2015-June, 2017. (Color figure online)

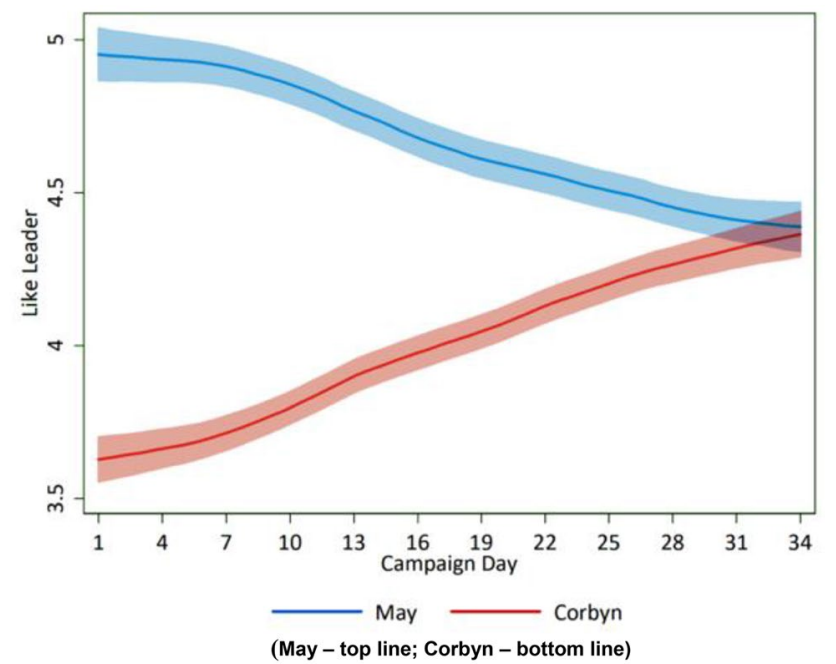

Source: Parliamentary Affairs 71(4), October 2018, pp. 719-737, https://doi.org/10.1093/pa/gsy001

Fig. 2 Leader like ratings over the campaign. (Color figure online)

the Leader's office, and the majority of both the parliamentary party, and the party machinery (Labour 2020). These performance teams included strategists, campaign 
directors, secondees, policy writers, speechwriters, digital gurus, spin doctors, social media managers, union leaders (in the case of Labour), data experts, and of course the lead actors - the candidates-themselves. ${ }^{2}$ The goal of all these workers was to shape the national ritual, intervene in the news cycle, percolate their message down through countless door-knocking activists, and ultimately to extend their 'definition of the situation' to the voting public, largely via a complex multifaceted set of media. However, as in any other arena of activity, in large-scale political dramas the best laid schemes o' mice an' men, gang aft a-gley, and this paper also demonstrates how the success or failure of these cultural workers' efforts was constrained and conditioned by two more unyielding, objective factors, the first more material, the second more symbolic.

First, material contexts condition the experiences of audiences whom political performers seek to convince. This is not to return back to a crude materialism which sees such contexts as 'in the last instance' ultimately determinate, or in no need of symbolic rendering for their meaning (which is of course an essential aspect of experience) to become established. Prior to the General Election, a profound transformation in many citizens' material conditions had occurred, not in an unmediated fashion, but neither in an entirely hermeneutically open manner. This transformation shaped citizens' lifeworlds. Beginning during the Thatcher years, continuing through Major's reign, morphing but ongoing through the Blair-Brown era, and intensifying during the austerity years following the 2007-2008 global financial crisis, these changes provided the contingent backdrop against which the election drama played out. The cultural story that free markets improved everyone's lives was failing to be borne out in lived experience. The rise of foodbanks, in-work poverty, homelessness, unaffordable housing, stark deterioration of public services, precarious work conditions, and material inequality jarred with any narrative of equally shared material advancement. The 'concrete situations in which ... cultural models are enacted' do not 'determine which take route and thrive, and which wither and die' (Swidler 1986, p. 280), but such concrete situations certainly influence the likelihood that cultural work will succeed or fail via the mediating category of experience (Thompson 1978). During the election, the 'symbolic action' (Burke 1966; Turner 1974) of the competing performance teams succeeded or failed partly on the basis of its elective affinity with these lived experiences, which were themselves both materially and symbolically shaped. Borrowing terminology from framing theory, we might want to say that whilst resonant frames establish credibility in the here-andnow through their consistency, and through the trustworthiness of their articulators, underlying material conditions influence the salience of such frames by shaping their commensurability with audiences' lived experience (Benford and Snow 2000,

\footnotetext{
${ }^{2}$ Whilst they were not always working towards shared goals, amongst others, important members of Labour's performance team included such 'proximate actors' as Seamus Milne, Karie Murphy, Andrew Murray, Andrew Fisher, Tom Watson, Ian Lavery, James Schneider, Andrew Gwinn, Len McClusky, Iain McNicol, Steve Howell, Jem Bendell, Marc Lopatin, John Trickett, Jack Bond, and the spotlight protagonist himself, Jeremy Corbyn. The Conservatives' performance team included, most importantly, Lynton Crosby, Nick Timothy, Fiona Hill, Stephen Gilbert, Mark Textor, John Godfrey, Jim Messina, Craig Elder, Tom Edmonds, and Theresa May as the lead front stage actor.
} 
p. 621). This paper therefore argues that cultural workers must indeed be analysed as genuine agents but in a manner that avoids reducing broader social processes to purely self-directed ones.

Second, this paper will draw upon, and attempt to develop, another aspect of the 'strong program' toolbox to argue that symbolic structures matter, and that they sometimes do so to such an extent that they subvert cultural workers' own intended symbolic action, generating unintended consequences. ${ }^{3}$ Civil sphere theory argues that political elections involve struggles to locate one's own candidate on the sacred and civil side of various sets of binary codes, and demonstrate that one's opponent belongs on the profane, anti-civil side (Alexander 2006, pp. 53-67; 123-132). These potent binary sets, which taken as a whole constitute the 'discourse of civil society', are arrayed in opposition and distinction and configured into associations that are linked to one another through allusion, metaphor, and analogy. However, successful politicians cannot content themselves with the task of classification-simply arranging motives, relations, and institutions within the statics of these symbolic binaries. They must go further by spinning dynamic and compelling narratives out of the fixity of this underlying 'skeletal structure' (ibid., p. 60).

This movement from arraying symbolic sets to crafting meaningful sequences, involves building a plot-a convincing story of how we got to where we are, and different prognoses of where we might be heading, depending upon the political decisions we make in the here-and-now. In its most simplified and common form, a plot involves an initial situation giving way to a change or reversal in that situation, which then leads ultimately to a revelation made possible by that change or reversal (Polletta 1998). Successful plots also commonly include ambiguity and ellipses, which serve a crucial role in retaining our engagement and interest in such stories (ibid.). Audiences stay gripped because they want to find out how things will turn out. If such denouements were revealed all at once, the pull of the narrative would be lost. In the case of fiction dramas, before the plot is fully revealed, audiences resolve these ambiguities or fill in these gaps through their imaginations, but in real democratic dramas they can also be overcome through efforts to draw audiences into the narrative themselves as actors, with the goal of directing the story towards a conclusion the audience wishes to see. It is for this reason that narratives can provide such irresistible political mobilising devices (Salmon 2010).

Plots also need to be personified for a public audience-populated by a limited number of heroes and antiheroes that condense, simplify, and epitomise broader processes or values. The public focus on this limited number of outward-facing personas-what Victor Turner called the 'star groupers' (1980, p. 152)—can often act to conceal the more extensive performance teams lying behind them, even it is often decisions made by such performance teams that in part determines the 'felicity' (Austin 1955; Goffman 1983) of the star groupers' public performances.

Finally, good stories are usually shaped around established genres that allude to common stories with which audiences are familiar (Frye 1957; Polletta and Callahan

\footnotetext{
3 Describing such consequences as 'unintended', does not rule out the possibility that they might nevertheless be anticipated by the cultural workers that produce them (Baert 1991).
} 
2017, p. 394; Smith 2005). Such uses of narrative are especially significant to democratic struggles over power, thus coming particularly to the fore during political campaigns (Salmon 2010; Alexander 2; Mast 2012; Hochschild 2016; Polletta and Callahan 2017).

This paper will suggest that these ingredients of meaning-making have their own structuring power, or 'cultural logic', that often works against cultural workers' deliberate intentions. Since, for instance, it is not arbitrary cultural content itself, but similarity and difference that builds meaning (de Saussure 1893/1915, p. 122; LeviStrauss 1967a; Barthes 1993), agents' efforts at positioning specific content on one side or another of a symbolic binary can, if it contradicts this formal structure, or contravenes the sequential rules of plot, often end up thwarted. Put more succinctly, 'systemic codes retain an autonomy by virtue of their formal logics' (Alexander and Smith 1993, p. 160). In what follows, I will try to illustrate various instances of this occurring.

One way is through what I have called 'code-rerouting', whereby certain 'signifiers' are rerouted to correspond to alternative 'signifieds'. Allied cultural sociological concepts have been developed in order to account for the power that codes and narratives hold over determining the success or failure of action, as well as how such action can itself reshape such codes and narratives. It has been shown, for instance, how narratives can become inflated, deflated, reclassified, deconstructed (Smith 1994, 2005), and inverted (Acevedo et al. 2010) in public dramas, how cultural codes are frequently hybridised (Lo and Fan 2010; Baiocchi 2012; Guana 2016), and how contentious political performances often draw their power from condensing or displacing (rather than necessarily conforming to) dominant culture structures (Gauna 2018). The notion of 'code-rerouting' introduced in this paper intends to capture both sides of this 'structuring' and 'structured' dynamic. It does this by showing both how cultural agents in the election campaign were in some instances able to direct assumed signifiers towards alternative (non-assumed) signifieds, but also how in other instances, the formal logic of codes themselves sometimes frustrated culture workers' efforts at making certain significations stick. The Situationists also theorised such code-rerouting processes through what they called 'détournement' (Debord 1957; Debord and Wolman 1956), but they did so through a model in which cultural workers initiated such processes as a form of artistic propaganda. Whilst providing illustrations of this agent-led process occurring, this paper will go further in showing how 'culture structures' (Rambo and Chan 1990) themselves, due to their inherent paradigmatic rules of homology and opposition, as well as their syntagmatic rules of chronology and succession, can also control such codererouting processes, and frequently do so in subversive opposition to agents' own intentions.

Similarly, the paper highlights how lack of performative coherence can be fatal to the outcome of the cultural work that goes into projecting political narratives. If a particular political performance is not perceived to cohere on a formal level-e.g. between individual and icon, between surface and depth, between past and present, or between one's private and public image - its likely felicity is thrown into jeopardy. Finally, the paper also illustrates how culture structures are able to influence outcomes through showing how failure to conform to the structuring norms of civil 
rituals - such as presenting oneself to public scrutiny during an election campaigncan severely damage one's overall performative success.

Although the sharing of personal motivational narratives-what Marshall Ganz (2009) has called 'stories of self' - was an essential feature of the countless canvassing interactions between activists and prospective voters (Nielson 2012), the empirical body of this paper is organised around three key aspects of Labour's broader metanarrative, which was projected by the centralised performance team during the campaign and which shaped and framed these focussed micro-interactions.

The first aspect (Part I) was its emphasis upon providing a political alternative to a paralysis narrative that presented globalised liberal capitalism as the ultimate horizon of legitimate politics, and ongoing domestic austerity as the only viable and necessary solution to eliminating the national budget deficit. It will argue that the latter failed to conform to many well-known rules of convincing storytelling, presenting the election as a fait accompli and providing no ambiguity or unresolved tension that a future Conservative government might overcome. Labour's narrative, by contrast, was dynamic, propositional, and partly unresolved, characterised by an undetermined (rather than foregone) conclusion. It will argue that these features helped activate audience participation by promoting the belief that such activity could bring about a conclusion to the story that the audience wished to see, in the process multiplying the scale of the 'performance team' at Labour's disposal.

The second aspect (Part II) was the dual position occupied by Corbyn himself as a principal protagonist within this story. One element of this duality was Corbyn as an idiosyncratic individual, thrust unexpectedly into a position of leadership he did not actively seek. The other element was Corbyn as an icon: an emotionally charged totem for a far broader democratic movement, and a collective representation for an array of political hopes, shared sentiments, and salvation.

The third aspect (Part III) was the use of two alternative stages from which to project its narrative: rallies and social media. Large rallies offered formidable images capable of undercutting the dominant media narrative and provided possibilities for ritual 'fusion' amongst attendees. The organic use of digital media offered invitations into the broader narrative, activating those that engaged, whilst at the same time opening up risk. It will show however, that efforts to control risk in political dramas can ironically end up inviting it, through killing the spontaneity that grips audiences and dampening the emotions that feed political enthusiasm.

Inevitably in political scenarios, narratives face counter-narratives, and the paper will simultaneously try to show how these three aspects of the Corbyn narrative were challenged by attempts to attach them to anti-civil motivations, relationships, and institutions. Using the same framework, it will try to explain the constraints on the success of these counter-narratives by on the one hand demonstrating the performative failings of the cultural workers and the teams they operated within, and on the other, revealing the tensions between these performances and the culture structures in which they were enacted.

Recent histories of the Labour Party (e.g. Thorpe 2015; Fielding 2002), including those focussed on the changing fortunes of the left within it (e.g. Kogan 2019; Hannah 2018; Fielding, forthcoming) provide the broader context in which the Corbyn phenomenon unfolded but their overriding focus on the instrumental, 
material, and technical factors (e.g. rule changes in party leadership elections) that allowed for Corbyn's ascent has tended to mistake necessary for sufficient conditions. Political journalists have also published extensive studies of the 2017 election (e.g. Shipman 2017; Ross and McTague 2017; Jones 2020, pp. 126-163; Pogrund and Macguire 2020) and other popular books focussing on Corbynism in particular have been written by speechwriters, advisors, and journalists (e.g. Nunns 2018; Howell 2018; Prince 2016; Bower 2019). These texts provide excellent source material due to their authors' extensive behind-the-scenes Westminster contacts, but tend to prioritise anecdote and parliamentary intrigue, lending themselves to a misleading understanding of political developments as the outcome of decisions, struggles, and coalitions between individual personalities. These accounts therefore tend to neglect the structuring influence of culture that this paper intends to highlight. Studies of the election by political scientists (e.g. Cowley and Kavanagh 2018; Heath and Goodwin 2017; Tonge et al. 2018; Allen and Bartle 2018; Wring et al. 2018) provide a more methodical treatment but have neglected sustained engagement with the dramatic, performative, and symbolic factors that I argue are indispensable for a holistic account of the election's course and outcome. Other academic monographs (Bolton and Pitts 2018) have critiqued the political assumptions which they claim that Corbynism rested upon, but again neglect to explain its dramatic appeal. Drawing upon a cultural sociological literature focussed mainly upon American political dramas (e.g. Alexander 2012; Mast 2012; Mast and Alexander 2019; Polletta 2006; Smith 2005), this article seeks not to provide a theoretical assessment of the inherent political viability, coherence, or desirability of Corbynism, but instead-relying upon analysis of the rich symbolism found within political contests - a meaningbased explanation of one of its shock performances.

\section{Telling an alternative story}

'What the Conservatives must do: ... ultimately frame the election as a choice between continuity and stability, or chaos and uncertainty'

- Strategy Note from Conservative Party Campaign Manager, Lynton Crosby.

'Labour - a real alternative for Britain ... How do we project our alternative? Not by business as usual'

- Strategy PowerPoint from Labour Party Director of Strategy and Communications, Seamus Milne.

After introducing the continuity narrative that dominated the political scene into which Corbyn's Labour was born and which the Conservatives chose to structure their electoral campaign around, this section will describe how Labour's own metanarrative confronted this story head-on. It did so by projecting its own narrative of the necessity of a political alternative. It will then argue that much of the oppositional work that in turn went into delegitimising Labour's narrative brought about the unintended consequence of in fact reinforcing it, in part due to the broader logic of the symbolic structures in which this cultural work took place. 
From the beginning of the election campaign, the audience was told-by the media, by dissenters within the party, and of course by the opposition-how the story would end: certain and humiliating defeat for Corbyn. This was a foregoneconclusion narrative with no ambiguity, no partially unresolved content. Confidence in this outcome derived its power from the fact that the General Election was merely a subplot in a much wider dominant continuity narrative in which it was clear to all sensible opinion that a politician cut of Corbyn's cloth stood no chance of success. This surety had established itself long before the General Election, during Corbyn's candidacy for leader of the party in 2015, when many unlikely Labour MPs nominated him in the comfortable certainty that his bid would fail. Ladbrokes, the betting company, put his odds at winning the leadership at 200/1. Once it looked as if he might, unexpectedly, stand a chance of succeeding, many Conservatives openly supported his campaign, believing his success in the leadership race would inevitably bury the Labour Party for a generation. ${ }^{4}$ With respect to the 2017 General Election, apparent confirming evidence for this dominant narrative could be found wherever one looked: when the election was called one poll had Labour on literally half the percentage points of the Conservatives (24-48\%) (Kantar 2017), and even two and a half weeks into the election, the local elections saw a swing to the Tories of 563 councillors and a gain of 11 more councils.

Politics, however, was clearly moving faster than the commentariat and most political scientists could make sense of, and becoming much more volatile both throughout Europe and across the Atlantic. Both the UK's vote to leave the European Union and Trump's election three months earlier confounded all ostensibly well-informed opinion. Traditional liberal democratic parties were in freefall across continental Europe, challenged by demands for more thoroughgoing change from both left and right. Corbyn's own rise from the periphery of political life to its centre had not only been a dizzying ascent to power that almost nobody foresaw, it had also occurred in the absence of any apparent personal ambition.

As the election campaign moved forward, and the dominant narrative of Corbyn's apparently already vanquished status unravelled, narrative allusiveness- the manner in which 'we glean a story's [moral] point by reference to stories we have heard before' (Polletta and Callahan 2017, p. 394)—began to take hold. Displays of omnipotence tend to invite fantasies of their destruction, and combined with a savvy 'populist rebranding' that had taken place the year previously (Stewart and Elgot 2016), expectations of Corbyn's defeat were transfigured into narratological advantages. Corbyn became recast as a 'dark horse', an 'underdog', a David representing 'the many' against a Goliath representing 'the few'.

In his Labour Party leadership victory speech, Corbyn set the tone for the insurgent narrative that would go on to dominate the reformed party under his direction and unify the message of the 2017 General Election. He declared 'we don't have to be unequal, it doesn't have to be unfair. Poverty isn't inevitable. Things can, and they will, change' (Corbyn 2015a, my emphasis). In essence, this narrative focussed

\footnotetext{
${ }^{4}$ Former Tory MP Louise Mensch, for instance, mockingly changed her Twitter profile picture to include the strap-line: 'Jeremy Corbyn for Leader' (Perraudin 2015).
} 
on the necessity of a political alternative to what it framed as a dead-end, continuity story that had silently established itself as a consensus across both the centreleft and centre-right political imagination. On the more general level, this dead-end narrative presented a certain form of globalised liberal capitalism as the ultimate horizon of legitimate politics, and on the more specific level, it presented economic austerity and 'fiscal responsibility' as the only conceivable answers to balancing the national budget deficit that had expanded rapidly following the 2007/8 global financial crisis. Prior to Corbyn's leadership, such opinions had commanded bipartisan support across parliament, establishing themselves as an unspoken common sense (Gramsci 1971, pp. 423, 330f). Under this consensus, politics had-in the words of one of the sociological architects of this political approach-moved 'beyond left and right' (Giddens 1994) and General Elections had to a large extent become diminished to efforts at symbolically triangulating towards one's opposition in an effort to capture a mythical 'centre ground' upon which electoral success was apparently won. On the back of countless focus groups, Labour had promised to get friendly with big business and tough on immigration, whilst the Tories had tried to shed their image as the 'nasty party', and reinvent themselves as champions of social liberalism and 'compassion', introducing gay marriage legislation and proposing to tackle youth crime by 'hugging a hoodie'. At the height of the dominance of this narrative, electoral turnout and party membership were at record lows across Europe (Mair 2013). Setting this narrative's content aside for a moment, its primary formal weakness was that it in fact offered no genuine narrative at all, no sense of moving from one historical moment to another. It instead presented an impasse, a 'post-historical' political landscape (Fukuyama 1992) that implicitly accepted Thatcher's famous declaration that 'there really is no alternative'. Politics operating within this impasse was of a managerial, immobilised, technocratic, and what Colin Crouch (2008) has called a 'post-democratic' sort, since all the fundamental normative questions had apparently been settled (Morgan 2020b).

Leading up to the 2017 election, the UK political scene had been defined by austerity even though its architects had pledged it would be over by the time Corbyn ascended to the leadership of his party in $2015 .^{5}$ Yet 5 years after the initial announcement of major spending cuts -7 years, by the time of the General Election-austerity persisted, and its popularity, perceived necessity, and perceived fairness was rapidly waning (Dahlgreen 2016; Reuters 2017; YouGov 2017a). A political narrative projecting 'more of the same' is threatened under such conditions, whereas a story asserting that 'things can, and they will, change' promised to connect with what Hochschild has called the 'deep story' of a large segment of the British audience-electorate. A 'deep story' is a 'narrative as felt', a 'story that feels as if it were true' (Hochschild 2016, pp. ix, 16, 135-153), and in the UK context-in which inequality was widening, wages were stagnating, and public services were deteriorating under successive rounds of cuts — this 'deep story' responded to

\footnotetext{
5 Chancellor George Osbourne had promise that he would be 'tougher than Margret Thatcher' in tackling Britain's budget deficit.
}

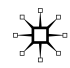


an intuitive rhetorical question: if it was not ordinary citizens who had caused the crisis, why should it be them who continue to pay for it?

The Corbyn narrative marked a decisive break not only from the government's thinking, but also from that of the Labour Party's recent past, both in a more pronounced way from the New Labour era, but also from the period directly preceding Corbyn's election to the leadership. Prior to the 2015 General Election, Shadow Chancellor Ed Balls had promised to reverse none of George Osbourne's budget cuts (Balls 2015), and following Labour's defeat in that election, acting leader Harriet Harman had whipped Labour MPs into abstaining on the government's proposed cuts to welfare. Following the campaign for a leader to replace Ed Miliband, one of Corbyn's challenger's for the post, Liz Kendall-who was widely considered to be the Blairite contender-candidly reflected that a key reason she had ended up with $4.5 \%$ of the vote, compared to Corbyn's $59.5 \%$, was that members 'didn't feel that I set out an inspiring enough alternative for the future' (Stone 2016, my emphasis). The pre-Corbyn Labour Party was not unique in this respect, the capitulation of established social democratic parties to the master narrative of what - to inadequately condense a broad set of ideas and policies into a single word-might be called 'neoliberalism', was fairly comprehensive across Europe. This led to a dramatic decline in support for such parties during the 2010s, via a process of what is sometimes called 'PASOKification' in reference to the most precipitous instance of this trend occurring in Greece. What marked the UK as unique in comparison to many other European countries, was that the challenge to this master narrative arose from within, rather than from outside, the traditional social democratic vehicle.

In first-past-the-post democracies it is especially important during elections to construct a coalition of voters out of otherwise divided yet overlapping social groups. For Corbyn's Labour, a potential electoral coalition included, among others, public sector workers, the 'traditional' working class, students, the precariat, university graduates, Clause IV socialists who had abandoned Labour during the Blair/ Brown years, frustrated renters, progressive middle-class liberals, jobseekers, disabled activists, and Scottish voters that Labour had previously lost over the national question (Skinner and Mortimore 2017; Milne 2017). Just as broadly compelling stage performances simultaneously project different meanings to different elements of their audience, so performative felicity in first-past-the-post elections depends upon bridging constituencies and articulating their distinctive hopes and grievances in a convincing and coherent way. ${ }^{6}$ In an effort to successfully articulate such segmented social interests (Laclau and Mouffe 1985), the Labour narrative aspired to glue these groups together around a shared story of where the country had been, where it currently was, and where it might be heading in the future. It aspired to sew together outrage at transgressions of particular moral economies (Thompson 1971; Scott 1977), with harms felt directly through material hardship. To the extent that it

\footnotetext{
${ }^{6}$ In a behind-the-scenes strategy discussion, Greg Philo, for instance, argued that 'we are seen as defenders of the weak and oppressed-and so we should be! Still, we need to go beyond this - the middle classes are also affected by increasing insecurity, fears over jobs, pensions, health and education. We should talk about ... the need for a national renewal' (in Howell 2018).
} 
was successful in doing so, the Labour narrative could be said to have 'translated' sphere-specific concerns into more universalistic concerns of the British civil sphere (Alexander 2006, p. 209).

Their election manifesto, for instance, pledged to eradicate rough sleeping within the first term of a Labour government (Labour 2017a, p. 64). Street homelessness is of course primarily an issue for those without a home, but it can also be translated into a more universal issue that offends securely housed groups on a symbolic and moral level, through threatening the civil value of mutual care. In his first speech as Party Leader, Corbyn addressed this topic through religious symbolism but in an unmistakably civil register, evoking a shared 'we' that is left ambiguous enough to refer to both the Labour Party, but also to the more universal solidarities implied by civil membership: 'we want to live in a society where we don't pass by on the other side ... [where] we reach out to end the scourge of homelessness and desperation that so many people face in our society. We are strong enough and big enough to be able to do that, which is what we are about' (Corbyn 2015a).

In order to invest the need for a new beginning with sufficient emotional draw, progressive narratives must demonstrate the moral imperative of abandoning the status quo. Within such narratives, the 'greater the difference between past and future in terms of perceived danger and moral urgency-damnation versus salvation; destruction versus rejuvenation - the greater the imperative for action' (Mast 2017 , p. 473). It was therefore crucial that issues such as foodbanks, homelessness, and social care reforms were constructed as civil crises during the election campaign. However, to convince an audience of the importance of moving from A to $\mathrm{B}$, demonstrating the dire situation of $\mathrm{A}$ is usually inadequate. This was a trap that much of the British left had arguably been stuck in prior to the Corbyn phenomenon: mistaking opposition for vision. For a progressive narrative to be successful, the attraction of reaching B must also be demonstrated. The Conservative campaign crafted a story characterised by a predominantly negative focus, aimed at polluting Corbyn and his associates. ${ }^{7}$ By contrast, the narrative of the Corbyn campaign was not only oppositional in its challenge to austerity, market-led development, and the encroachment of private enterprise into public goods, but also propositional in its emphasis on a constructive policy-led vision of hope that projected a more equitable future social arrangement. This was providing the electorate with something to vote for, rather than simply something to vote against. Furthermore, it presented a plot that was not entirely resolved; a conclusion that was not a fait accompli. It was an open-ended story that could be shaped by audience engagement in the present.

Fate conspired to draw special attention to this propositional element of the Corbyn campaign narrative when, on the evening of 10 May, it was announced that someone from within Labour's own ranks had leaked the draft election manifesto to the Telegraph and the Daily Mirror. Labour manifestos require endorsement by a meeting of the Shadow Cabinet or Cabinet (depending upon whether Labour are in government), the National Executive Committee (NEC), and union affiliates; a

\footnotetext{
7 Timothy Bell, Thatcher's PR advisor, blamed this 'entirely negative' approach on the lead agent in Conservative's performance team, the campaign manager Lynton Crosby (Beckett 2017).
} 
meeting that was scheduled for the following day, when the leak would hit the headlines. Labour had already begun a 'policy blitz' prior to the snap election, and three days before May's announcement, polling had revealed that most of these policies commanded overwhelming public support (Cowburn 2017). These policies had been incorporated into the leaked manifesto as commitments, and plenty of additional propositional policies were also added. The manifesto revealed that the promise of change established on the formal level of style was to be backed up on the substantive level of policy, presenting a genuine choice over the future direction of the country to the electorate. Most sensationally, the document contained plans to re-nationalise the railways, Royal Mail, electricity, and water, not overnight, but as private contracts expired. It also promised free school meals (by charging VAT on private school meals), a $£ 10$ minimum wage, the abolishment of university tuition fees, the reintroduction of educational maintenance allowances for poorer students, and infrastructure investment and cash injections for the NHS. Framing all these policy proposals was what Corbyn, in the Foreword to the document, described as Labour's promise of 'real change', in contrast to the Tory commitment to 'hold Britain back' (Labour 2017, pp. 4, 5).

If whoever leaked the document had done so maliciously, they were quickly hoisted by their own petard, to such an extent that there was speculation-consistently denied (Howell 2018, p. 145) — that someone from within Corbyn's inner circle had passed it to the press to gain coverage and force it through the endorsement meeting. Not only did the revealed policies go on to lead the news agenda, but during the following week or so they also provoked-as the pre-election polling had indicated they might-Labour's biggest polling upsurge throughout the election, even more rapid than that which had occurred following May's initial announcement. Voter registration almost doubled as a result (Electoral Commission 2017), in large part from young people who overwhelmingly went on to vote for Labour (Young 2018). Age, in fact, turned out to be the strongest variable-defined predictor of voting behaviour, with one's likelihood of voting Tory, and not voting Labour, increasing 9 points with every 10 years of age (Curtis 2017), and a staggering $61.5 \%$ of under-40s voting Labour, compared with only $23 \%$ of this age group voting Tory (Pasha-Robinson 2017). Seen in the broader context of post-war reforms, the manifesto policies were not particularly radical, amounting to a reassertion of core social democratic aspirations, some relatively mild income redistribution, moderate worker empowerment, and a strengthening of a welfare state that had been incrementally depleted over decades. Plotted within the post-Thatcher common-sense consensus discussed above however, these proposals constituted a decisive, and indeed highly radical break, demonstrating just how far the structural 'centre' of mainstream politics had been shifted to the right since the 1980s. In response, oppositional storytelling began in haste.

Firstly, on the day of the leak (11 May), two national papers-The Daily Telegraph and the Daily Mail—ran with the same front-page splash: 'Corbyn's Manifesto to Take Us Back to the 1970s'. This counter-narrative aimed to paint the prospect of a Corbyn-led government as not a step forward, but in fact a return to the past, as offering a narrative of regression, rather than progression. Fitting the event within the broader fait accompli theme, comparisons to Michael Foot's 1983 
manifesto, famously dubbed by a dissenting Labour MP as the 'longest suicide note in history', abounded (e.g. The Economist 2017; Travis 2017; Daily Telegraph 2017; Zeffman 2017). However, given that a 'return to the past' still aligned with the symbolic coding of a 'change from the present', this counter-framing could in fact be used to reinforce aspects of Labour's own narrative (Table 1). This ushered in a series of counter-counter-frames gleefully welcoming a return to an era when public housing and public services had not been sold off, private housing was still affordable for young people, finance markets had not been deregulated, foodbanks and university debt were unknown, popular culture was blossoming, and working-class communities had yet to be decimated by the long Thatcherite revolution (Reade 2017; Steel 2017).

Secondly, the practical viability of Labour's proposals was brought into question by presenting the manifesto as an entirely unrealisable wish-list (e.g. Kettle 2017; Daily Telegraph 2017). This account was given brief legitimacy because the leak had included no costings. It was, however, quickly derailed via publication of these costings alongside the document's official release (Labour 2017b), and also-since the credibility of frame articulators is key to frame resonance - the Conservatives' later failure to provide their own (Kuenssberg 2017a). Significantly, in terms of coding, the economic viability attack did little to challenge the notion that Labour were indeed proposing an alternative to the prevailing socio-political dispensation. Moreover, compelling narratives are rarely dislodged by simple criticism, and especially not when this criticism reinforces central aspects of the story's formal structure. What is required are convincing substitute stories, and a forthcoming propositional substitute story was conspicuously absent from the Tory camp, stuck as it was within an oppositional and continuity approach.

Finally, as will be elaborated further in the following section, the Conservatives framed the leak as further evidence that Labour were offering disorder and uncertainty for the country, with May quick to argue that the leak revealed the 'economic chaos' that a vote for Labour risked (Collier 2017). Like the other charges, however, his attack preserved the 'change' vs. 'continuity' coding intact, even if it attempted to reverse the evaluative connotations attached to each side. In a rehearsal of a dynamic played out during the Brexit referendum, attempts to scare the public about what the manifesto was proposing ended up cementing the notion that Corbyn was indeed offering some kind of change.

Overall, in contrast to the Labour Party's metanarrative, the 'continuity and stability' framing (Crosby 2017) of the Tory campaign, alongside its presentation of the election outcome as a forgone conclusion, offered no sense of unresolved plot that might inspire audience participation. It therefore failed to offer convincing, dynamic, and motivating storytelling. Moreover, as the case of the manifesto leak illustrated, whilst the oppositional response to Labour's narrative may have successfully generated fear over the prospect of a Corbyn-led government, it nevertheless fortified the notion that Labour was indeed proposing a break. Formal logic precluded the possibility of meaningful arguing that Corbyn both posed a radical threat to the country's stability and at the same time that he offered no political alternative (Table 1). 


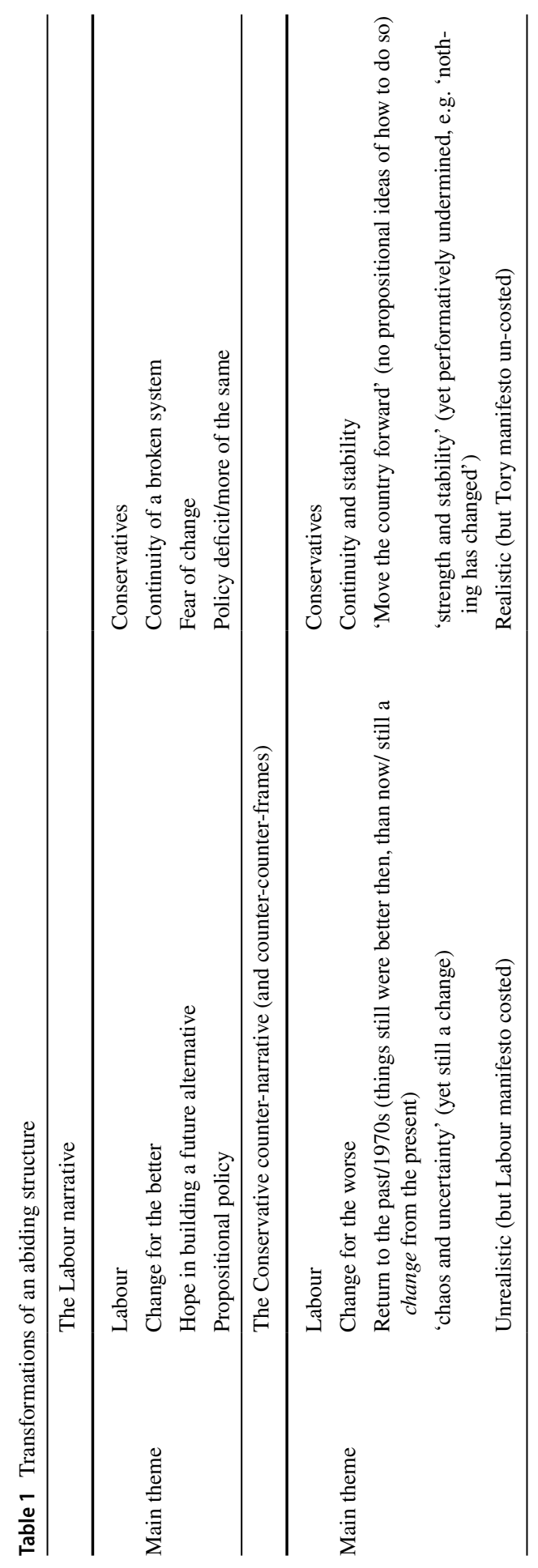




\section{The importance of coherence: Corbyn-as-Individual, Corbyn-as-Icon}

Compelling stories condense abstract ideas and simplify broader collective processes down into individual protagonists and antagonists who personify, epitomise, and act out these ideas or trends. If successful, dramatic identification takes place since audiences can more easily establish direct emotional connections with individual figures than they can with disembodied ideas or complex amorphous social bodies. This section will describe how Corbyn came to occupy a dual role within the narrative that was being forged around him. This dual role was composed on the one hand, of Corbyn-as-individual, with all the attendant idiosyncratic biographical details, and on the other, of Corbyn-as-icon, with all the sacred and universalising meanings that attach themselves to such figures. It will argue that to the extent that an apparent coherence was established between these two elements, as well as an apparent performative coherence between surface and depth, and over time and place, Corbyn's resonance was bolstered. Further, due to the relational manner in which meaning is established, it will try to show how this apparent coherence was strengthened by apparent incoherencies emerging in the performance of his primary dramatic antagonist and symbolic foil, Theresa May. Through interactional elaboration, May, in other words, helped buoy Corbyn's own charisma and legitimacy by playing a typical 'charismatic counter-role' in her part as an 'unworthy challenger' to Corbyn's insurgent performance (Joose 2018).

The first element of this duality was Corbyn-as-individual, thrust at a mature age and by extraordinary circumstances into a position of leadership he neither anticipated occupying, nor actively sought. This latter point is particularly important, given that distrust in democratic leaders often stems from perceptions that they are 'career politicians', more concerned with gaining power or office than in discharging the duties of that office or carrying out authentic representation. This taps into deeper binaries of civil discourse in which public distrust can result from the suspicion that particularistic motives are driving one's political ambitions (Alexander 2006, pp. 53-62). The whole period building up to Corbyn's nomination to stand for party leadership, as well as much of the leadership contest itself, had been accompanied by an open commentary from those who nominated him, the activists who supported him, and the media surrounding him (most of which looked upon his candidacy with a mixture of incomprehension and patronising amusement), claiming that he was only standing to 'broaden the debate' with no viable chance of winning (Prince 2016). Corbyn himself initially understood his candidacy within a similar frame, stating that his decision to stand was 'in response to an overwhelming call by Labour Party members who want to see a broader range of candidates and a thorough debate about the future of the Party' (BBC 2015), and elsewhere, that 'if I can promote some causes and debate by doing this, then good. That's why I'm doing it' (in Hattenstone 2015). A candidate from the left of the party was seen as necessary for reasons of political diversity and inclusion, and since the pool of such candidates was vanishingly small, and most of those experienced enough-most obviously Diane Abbott and John McDonnell-had previously stood unsuccessfully, the responsibility was thrust upon Corbyn's shoulders, rather than him actively seeking it out. 
This feature of Corbyn-as-individual was reinforced by his career choices, which typified what Mudde and Kaltwasser (2017, pp. 73-76) identify as a common feature of populist leaders, whether authentic or contrived: an 'insider-outsider' status, which often manifests in the figure of the 'reluctant politician'. The believable embodiment of this 'reluctant politician' figure has positive implications for one's perceived civility, since such a figure acts out of a sense of public duty rather than personal gain. Whilst it is true that Corbyn had been a professional politician for most of his career, it was also true that he had displayed almost no strategic ambition within his party, rebelling against it on more occasions than any other Member of Parliament (Cowley and Stuart 2008, p. 55). Rather than the pursuit of self-advancement, acquaintances have been more likely to criticise Corbyn for an obstinate fidelity to political causes often at the expense of more particularistic non-civil relationships, solidifying a public image of a figure driven by autonomous and impersonal, i.e. civil, motives. Corbyn's second wife, for instance, suggested that his recalcitrant opposition to selective education had 'played an important role' in their separation after she decided to send their child to a grammar school (Gentleman 1999). Public legend had it that he had also missed his son's birth, busy lecturing unionised workers elsewhere in the maternity hospital (Wheeler 2017). This image was further bolstered when perhaps the most damaging recent event for civil trust in the British political establishment - the parliamentary expenses scandal-broke in 2009, and it was revealed that whilst other MPs had been busy spending tens of thousands of pounds of public money to refurbish their second homes or clean the moats surrounding their country estates, Corbyn had claimed the least, just $£ 8.70$ for a printing cartridge (Hussain 2010).

Paradoxically, the relentless assaults on Corbyn's character, especially those received during the General Election, likely contributed to establishing his dramatic transformation from a marginal and mundane figure to 'a leader with theatrical power of unprecedented proportions' (Richards 2016, p. 12). This seemed to occur by providing opportunities to display civility through a refusal to respond in kind-'I don't do personal' was a common refrain of Corbyn's during interviews (Hattenstone 2015), and the interpersonal generosity his displayed towards merciless political opponents was an enduring source of both frustration and admiration for his supporters. Since narratives are typically generic (Frye 1957), the attacks on his character could be used to reinforce a 'dignified underdog' genre in which Corbyn resisted allowing public attacks to corrupt his own moral compass. This had been established early on, when during his first speech as conference leader, he called for an end to 'personal abuse', and a 'kinder, more caring politics' (Corbyn 2015b). Goading provided the chance to demonstrate civil qualities of self-control, equanimity, reason, and cool-headedness, bolstering an image of a figure who may respond well under other kinds of pressure. Typically gentle in his demeanour, Corbyn often came across as oblivious to the unprecedented hostility he was personally receiving, and though irritability with journalists did occasionally surface, actual anger was usually reserved only for perceived political injustices (e.g. Bulman 2017). This public display of composure was especially evident during the General Election campaign, when Theresa May's former 
head of communications described Corbyn as appearing to have taken the world's 'biggest chill-pill' (Kuenssberg 2017b).

As in stage performance, costume also plays an important role in political drama and dismissing its superficiality, ignores the manner in which deeper meanings are projected and read off surface signifiers (Simmel 1957; Hebdige 1979). Corbyn's sartorial decisions not only provided a seemingly inexhaustible vein to be mined by journalists wishing to avoid coverage of Labour's policy proposals, but also immediately marked him out as distinct from the Westminster cookie-cutter. Media reports typically focussed on how Corbyn's moderately casual dress sense signalled a damning lack of respect for high office. Although, in the face of resistance (Nunns 2018 , p. 109), his team eventually persuaded him to smarten up a little, his relative lack of formality remained, provoking David Cameron in one Commons exchange to instruct Corbyn to 'put on a proper suit, do up your tie, and sing the national anthem' (BBC 2016). The addition of this last clause in Cameron's outburst illustrated the ease with which surface symbolism can be tied to deeper (in this case, nationalistic, and indeed class-based) values, but precisely for this reason, the logic could cut both ways, and Corbyn's dress sense could also be used to project other symbolic coherences from surface to depth.

For instance, whilst the dominant attention to Corbyn's clothing aimed at either ridicule or as further evidence of his lack of Prime Ministerial gravitas, 'codererouting' also occurred. This process involved the anti-civil significations of his dress being rerouted to signify civil qualities instead. Since it could be agreed that his style was in no way a PR confection, his costume could just as easily be used to signify the 'political alternative' narrative discussed in the previous section by symbolising a decisive break from the spin-era of smart suits, thus strengthening the anti-establishment ethos he intended to represent (Stewart and Elgot 2016). Whilst the signifiers remained stable, cultural work meant that the signifieds were open to switching. In a BBC clip from the 1980s that was dug up and widely recirculated on social media during the 2017 campaign, a somewhat unkempt Corbyn stands beside a pinstriped and waistcoated Conservative MP, defending his decision to wear a jumper knitted by his mother and a shirt 'from the Co-op' around the House of Commons (BBC 1984). Significantly, Corbyn's defence of his attire rested on practical but also democratic and civil grounds: 'it's not a fashion parade, it's not a gentleman's club, it's not a banker's institute, it's a place where the people are represented ... late at night here, it's quite disgusting; after the dinners are over, and the division bell rings for ten o'clock, there're fleets of limousines that pull up, and out get large Tory MPs, with even larger stomachs, wearing dinner jackets, as they stride in to vote.' Reporter: 'Aren't you jealous?' Corbyn: 'Not at all ... I don't think that's the job of an MP; the job of an MP is to represent their people'.

Corbyn's pastimes also inevitably became the subject of media scrutiny. In interviews he revealed his interest in making jam, photographing manhole covers, the history of the railway system, vegetarian cooking, tending his allotment, and his relationship with his disappointingly individualistic cat, 'El Gato'. Whilst a passion for documenting drain entrances risks mockery, it was clearly not the fabrication of some slick spin doctor. Corbyn's support for his local Arsenal football club seemed natural in a way that David Cameron's capacity to forget the team he supported 
seemed to expose its contrivance (Boffey 2015). Not only did these quirks help humanise Corbyn, revealing a man of simple-to some, endearing-idiosyncrasy, but like his style, they also allowed for the demonstration of coherence between surface and depth, signalling civil qualities of authenticity as opposed to artifice, homologous with moral values of honesty as opposed to deception.

Finally, Corbyn's widely known background in movement politics and lifelong commitment to campaigning within and beyond parliament, meant that his viewswhether or not one agreed with them-were at least seen as sincerely held, another element that fed into the possibility of building a sense of coherence extended over time and place. This coherence might be considered in updated Weberian terms as what Reed calls a charismatic 'spiral of success', in which 'iterative, self-referential' performances over extended periods of time help bolster and build an individual's charisma, so that it 'develops into a challenge to extant powers' (2013, p. 284). Having cut his teeth in movement politics - around issues such as apartheid, the Trident nuclear weapons system renewal, Palestinian and Kurdish rights, and the invasion of Iraq ${ }^{8}$ - Corbyn's newfound centrality to parliamentary politics was itself buoyed by the spirit of movement politics: the 'excitement; the dynamism; the heady, disorienting feeling of the impossible becoming possible' (Nunns 2018, p. 125). Movement politics are concerned with 'the attempt to move from one situation to another that lends it the name, and a successful movement grows through this motion, like a snowball moving down a hill' (ibid.; cf. Diani 1992; Snow 2013). This dynamism and 'snowball' effect was also what lent the organisation whose purpose it was 'to build on the energy and enthusiasm of the Jeremy Corbyn for Labour Leader campaign' its name: Momentum (Momentum 2015). Corbyn's voting record in parliament, and his well-documented campaigning outside it were consistent with his claim that his 'basic attitudes and principles are pretty much as they've always been' (BBC One Show, 30 May 2017). This coherence was demonstrated through actions more than it was claimed through words, such as in his decision, immediately after learning of his sensational Labour leadership victory, not to relax or celebrate, but instead to address a pro-refugee rally in Parliament Square. Garrido has argued that supporters of the populist Filipino leader Joseph Estrada continue to vote for him 'because his political performance engages their expectations' (2017, p. 647). Corbyn's politics could similarly be presented as 'an expression of a deeply held disposition' (ibid, p. 680), rather than subordinate to some stratagem necessary for election.

The second, related, element of the Corbyn composite was Corbyn-as-icon: Corbyn as an emotionally charged totem for a far broader movement, and a collective representation for an array of political hopes and projections. As an icon, Corbyn became sacralised, set apart, and transcendent - an object around which ritual activity could focus. To his critics, this led to charges that he was the figurehead of a political cult; but to his supporters he was the crest of a wave, the democratically ordained representative of a movement.

\footnotetext{
${ }^{8}$ Corbyn was a founding member of the Stop The War Coalition, which he chaired, following Tony Benn, from 2011.
} 
Just as the surface quirks of Corbyn-as-individual could signify a deeper set of values, so Corbyn-as-icon could become a hypostatisation of shared commitment. To his supporters, he symbolised the reassertion of the civil qualities of fairness, representation, justice, equality, and straight-talking, back into political culture, and as outlined above, he also became an avatar for the return of history in a context of insipid continuity. These characteristics of Corbyn's iconicity again cohered with his more directly democratic style of leadership, in which he presented himself as a conduit through which others might speak. The novel decision to use the weekly PMQs session to read out emails he had received from members of the public, for instance, positioned him as vox populi-a tribune for public concerns.

In spite of this, many derided the public enthusiasm shown for Corbyn as hero worship. The collective affect surrounding him at rallies dovetailed effectively with Corbyn's movement-based mode of doing politics, but signalled an unprecedented and, for many, confusing channelling of emotion towards a mainstream British politician. This impulse towards rallying around Corbyn was in part another unintended consequence of the perceived injustices he had received, themselves made sense of through the underdog narrative adopted by his supporters, and reinforced through principles of mutual aid and solidarity long-established within British left-wing culture (Williams 1958, pp. 325-335; Thompson 1963, pp. 781-915; Todd 2014). However, it was combined with a sacralisation of the project, as much as the individual. 'A movement, not a man' became a popular slogan, \#WeAreCorbyn periodically trended online. It was not, therefore, simply that Corbyn derived a charismatic aura from the devotion of his followers (Weber, [1922] 1978, p. 242), but that his figure became a hypostatisation of these followers' own political hopes and fears.

Whilst dangers no doubt lurk in political personality cults, especially when they serve as a substitute for democratically led change, many of the po-faced concerns of hero worship missed the slightly ironic manner in which much of the adulation was conducted. Unlike the cultivation of more conventional super-heroic icons that has occurred in the case of recent American presidential candidates (Alexander 2010, p. 66), Corbyn's heroic iconicity was just as likely to be represented through memes of him raising a speaker as though it were a boombox, or cheekily grinning whilst holding an enormous prize marrow. Something about how his unassuming nature had so deeply unsettled the British political establishment leant him a powerful but understated air of mischief. The production of Corbyn's heroism was therefore a somewhat tongue-in-cheek exercise given his self-effacing personality, the unexpectedness of his rise to political fame, and his evident lack of the egoism upon which cults of personality have historically been built. All this no doubt also helped diffuse some of the initial seriousness with which the oppositional scaremongering was received.

Nevertheless, counter-narratives worked away at both elements of the Corbyn composite. Code-rerouting was again initiated, and Corbyn's past political activities, taken as civil signifiers by his supporters, were rechannelled by his opponents towards anti-civil motives. Attempts were made by both the media and the government to contaminate the Corbyn-as-individual figure by presenting him as a terrorist sympathiser, a traitor, anti-Western, a Marxist, a detached metropolitan, an anti-Semite, a threat to national security, even a spy for a foreign power. Most of 


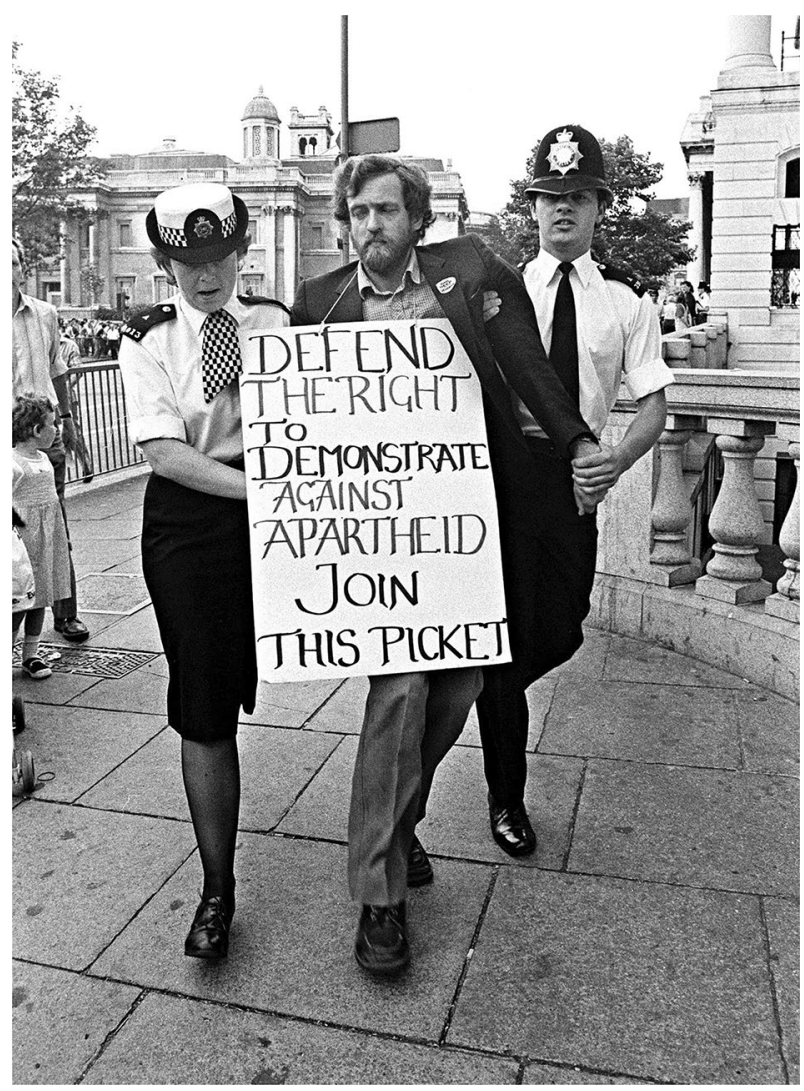

Fig. 3 Corbyn arrested whilst protesting outside South Africa House, London, 1984, Credit: @ Rob Scott Photography

these attacks focussed upon activity taken in relation to foreign affairs - an abiding interest of Corbyn's, which had gained him the unofficial moniker (never having previously occupied a ministerial, or shadow ministerial position) of the 'Foreign Secretary of the Left'. His engagement with Sinn Fein, his Palestinian solidarity, his campaigning on behalf of the Kurds, his criticisms of NATO, and his championing of nuclear disarmament were all provided as evidence of fundamental pollution and treachery. This was possible since these positions marked a distinctive rupture with what was conventionally expected of a leader of one of the two main parliamentary parties, and their meaning could therefore be thrown into contested civil territory, subject to public dispute.

As has been described, for his supporters, Corbyn's credentials as a movement veteran demonstrated civil authenticity and coherence. Photographs of him being arrested whilst protesting apartheid (Fig. 3) or addressing the largest demonstration in British history against the Iraq War were shared enthusiastically amongst his support base on social media. The images were taken to signify consistency and soundness of judgement in being on the right side of history at moments when right and 
wrong were yet to be settled in dominant political discourse. To his detractors, however, the associations he had made through his movement activism were incriminating proof of his willingness to engage in anti-civil relationships, his lack of loyalty to his country, and therefore his unsuitability for office.

The other side of the Corbyn composite was also attacked, by likewise revealing the anti-civil character of the movement that took the Corbyn icon as their totem. His supporters and their institutions, such as Momentum, were portrayed as 'a rabble', 'dogs', 'Trotskyite infiltrators', 'Militant Mk. 2', ${ }^{9}$ naive and brainwashed youth, conspiratorial plotters, and a fundamentally anti-democratic, potentially violent 'mob'. Sajid Javid, a possible future Tory leader, outdid the competition in describing Momentum as 'a neo-fascist organisation'.

Interestingly, the claims and counterclaims over whether Corbyn-as-individual was to be coded as pure or polluted, or whether Corbyn-as-icon was to receive sanctification or public defilement, all rested upon shared agreement over the semiotic sense of such oppositions. In other words, the coding disputes themselves masked the establishment of a broader consensus over the nature of civil discourse itself.

During the General Election, an unexpected event-the bombing of the Ariana Grande concert in Manchester on 22 May, two and a half weeks before polling day-provided the grim contingent backdrop for a demonstration of Corbyn's performative coherence. ${ }^{10}$ Cultural sociology teaches us that since events cannot speak for themselves, they must be spoken for in order for their meaning to become established. Collective traumas conform to this rule, so to become such, they have to be made. This process involves coding, weighting, narration, and identity (Alexander 2012; Eyerman 2019): what kind of trauma is this? Who is responsible? How severe? What is its meaning of this trauma within the larger story of us as a people?

23 people died in the Manchester bombing and 139 were wounded, many of them children. The youngest victim was just 8 years old. Campaigning was officially suspended in response but immediate speculation of the event's effect on the election inevitably arose. Most of the tabloids had been tireless in framing Corbyn as an apologist for terror, whilst strengthening the established image of the Conservatives as the natural party of defence. This image had also featured heavily in the Tory's own election campaign material (e.g. Conservatives 2017c) and an Ipso-Mori poll on the month the election was called had May beating Corbyn $57 \%$ to $18 \%$ on defence. Moreover, any pause in campaigning was widely seen as damaging to the momentum of the rising tide of support for Labour. Conventional wisdom therefore had it that these unforeseeable and tragic events would seriously harm Labour's campaign. However, at this sensitive time a high-risk decision was made by Corbyn and his senior advisors, in particular Seamus Milne, who both bolstered the metanarrative of Corbyn as offering a break from politics-as-usual, and provided yet another illustration of his performative coherence.

\footnotetext{
9 Militant were the British Trotskyist group (currently The Socialist Party) that were famously expelled for Labour Party entryism under Neil Kinnock's 1980s leadership.

10 The symbolic dynamics initiated in response to the Manchester bombing were later to be repeated when another terror attack took place on London Bridge just five days before the final poll.
} 
The decision was for Corbyn to deliver a speech on 26 May that would place the terror attack within the wider context of both British foreign policy, in particular the UK's involvement in Libya (where the Manchester bomber hailed from), and domestic austerity (a gesture to May's police cuts in her role as Home Secretary, prior to becoming PM). This construction of the meaning of the trauma was a position that anyone aware of Corbyn's past knew he would have naturally held, but it was also a position that had been excluded from the Overton window of acceptable discourse for a party leader, especially so soon after such a devastating event. As Andrew Murray, a Senior Advisor to Corbyn put it, "it would have been much easier just to say this is awful, we must simply condemn it and rely on anti-terrorist measures' (Ali 2018, p. 112). Although Corbyn's speech was very carefully worded so as not to 'reduce' the terrible acts to 'foreign policy decisions alone', and stressed that 'no rationale based on the actions of any government can remotely excuse, or even adequately explain' the events (Corbyn 2017), it was — somewhat inevitablyimmediately attacked by the Tories and much of the media for having done precisely that. Nevertheless, the breaching experiment paid off. A YouGov poll conducted the same day as the speech found that $53 \%$ of the public agreed with Corbyn's position, against $24 \%$ who did not (Smith 2017). What the poll arguably revealed was not only the media's disconnect from public opinion on such matters but also audiences' receptiveness to political performances that demonstrate a logical and moral coherence across time and place. What the speech both exposed and contributed to furthering, was a redefinition of the terms on which public legitimacy was built. In other words, rather than competing on predefined political ground, the speech helped establish Corbyn's charismatic authority by redrawing the rules of status competition (Joose 2018, p. 930). This had the added effect of casting Theresa May as an 'unworthy challenger', a rival made to publicly 'fail amid the newly established charismatic criteria' (ibid., p. 924).

May was to be pushed as a 'strong and stable' leader, a slogan that was first used when she announced the surprise election outside Downing Street, and then repeated ad nauseum throughout the campaign (Poole 2017). A vote for Labour was presented as a vote for a 'coalition of chaos', since within the initial Tory narrative it was inconceivable that Labour could win an outright majority, and they would therefore be forced to govern in an uneasy coalition with other parties. It was clear that the Conservatives were 'working the binaries' by simplifying the electoral choice between continuity and order under May, and the threat of chaos and disorder if Corbyn ever made it into government. Characters, scripts, and direction, however, are only successful to the extent that actors can ultimately pull it all off, and during the election, projections of 'strength and stability' were systematically undermined by May's awkward public performances, as well as by the very fact that she had called a potentially destabilising election after repeatedly promising the public she would not do so (Stone 2017). Moreover, May's risk-averse public performances during the campaign were firmly rooted in the conventional rules of political charisma; rules that had been actively redrawn by the Corbyn camp. As Corbyn's charismatic authority rose through the confident expression of a new political vision, so May's own charisma—grounded as it was in convention-diminished (Joose 2018, p. 930). 
When May called the election, her justification had been to simply expand her mandate in order to 'strengthen her hand' in the Brexit negotiations (Mason 2017). ${ }^{11}$ If there was any uncertainty at this stage, it was over the extent of her expanded mandate, not its existence. As the campaign progressed, the hubris dissipated, performative weakness was revealed, and the message shifted from expanding a mandate towards mobilising fear around the possibility of a Corbyn-led government. In a BBC interview, May warned that 'Jeremy Corbyn wants to sneak into Number 10', and on 20 May, she tweeted that 'if I lose just six seats, I will lose this election and Jeremy Corbyn will be sitting down to negotiate with Europe'. ${ }^{12}$ Leaving aside the manner in which such performances inadvertently cast Corbyn as the main protagonist of the election, the notion that the Leader of the Opposition would be sneaking into Downing Street through a democratic process triggered by the individual making the accusation was odd, and revealed a sense of vulnerability, and therefore also incoherence in its clashing with the 'strong and stable' mantra her performance team was promoting.

However, perhaps the most spectacular event that severed the correspondence between the signifier of 'Theresa May' and the intended signified of 'strength and stability', was the unprecedented decision to U-turn on a key manifesto policy during the campaign itself. When the Conservative Manifesto was published on 18 May, it included a Social Care policy, in which elderly citizens receiving care at home would be required to pay for that care, including through the value of their property, if they held assets of over $£ 100,000$. Since those who needed long-term care - such as patients with diseases like dementia-would be worst hit, a key player in Corbyn's performance team, Andrew Fisher, coined the phrase 'dementia tax' for the policy_an epithet that quickly stuck. 'Scandals are not born, they are made' (Alexander 2003, p. 177) and Labour figures quickly took to the airwaves and their social media accounts to argue that May was forcing those requiring care to pay for it with their homes. They were fortuitously assisted in their efforts by damning public criticism of the policy from the individual who had written the government

\footnotetext{
11 A success of the 2017 campaign was to shift the agenda away from May's intended 'Brexit Election' framing, something the party failed to do in 2019. Corbyn's perceived authenticity was gradually eroded between the two elections through prevarication on the question of a second referendum. The semiotic relations between the leadership and the opposition were also reconfigured by Boris Johnson's arrival in No. 10. After winning the leadership in 2015, Corbyn's conference slogan had been 'Straight Talking, Honest Politics' but the wedge issue of Brexit, driven in part by Corbyn's enemies within the partymany of whom initially called for the referendum result to be respected-now presented Corbyn as an equivocator. Johnson, on the other hand, touted the straight-talking 'Get Brexit Done' mantra. Corbyn's inward-facing attempt at holding together an obviously divided party could be presented as triangulation, allowing a redefinition of him as an establishment figure, manoeuvring to frustrate the referendum result. Working directly against the 'change' narrative described above, Starmer-then Corbyn's Shadow Brexit Secretary, now party leader-adopted the awkward position of agreeing to back an EU deal only if it retained the "exact same benefits as we currently have as members of the Single Market and Customs Union'. Widely interpreted as a thinly veiled Remain position (since it would be impossible for any deal to meet such tests), to an electorate energised by calls for change, asking for the same as what 'we currently have' sounded very much like continuity. Of the 54 seats Labour ended up losing to the Tories in the 2019 General Election, 52 were in Leave-voting constituencies.

12 The Conservatives ended up losing 13 seats, with Labour gaining 30.
} 
report into funding Social Care, Sir Andrew Dilnot. Four days of media storm later, PM May dropped the policy, but denied having done so. When questioned about this during a press conference a flustered May uttered the fateful words, 'nothing has changed; nothing has changed'. It was difficult, of course, to conceal that something - a flagship manifesto policy_had changed (Ross and McTague 2017, pp. 221-239). May's own seemingly erratic actions were yet again performatively undermining her symbolisation of 'strength and stability', and civil trust risked fracturing in the refusal to admit that a U-turn had in fact occurred. The more the obedient carpet-bombing of the 'strength and stability' slogan took place, the greater the incoherence seemed. As we shall see in the following section, this incoherence only grew as the campaign rolled on.

\section{The stages: rallies and social media}

What could possibly go wrong? A 67-year-old politician going on stage at a Libertines gig ... in front of 20,000 young people... on a Saturday night in a tough Northern town... in the middle of a General Election.

...What if the crowd boos him? What if they bottle him off? This is Birkenhead, not Glastonbury ... A crowd of mainly working-class Northeners has paid for a concert, not an election rally. Ordinarily, any one of these risks would be enough to keep a politician away...

“There's someone special who's come here to talk to you ... Please welcome Mr Jeremy Corbyn!"

The crowd erupts instantly. This is a good sign. There is even the sound of girls screaming. Unexpected.

"Look here," says Corbyn after 30 seconds of applause, "we've got football and music all in the same place." The crowd has not stopped cheering so Corbyn speaks in short bursts to make himself heard. He has simplified his message for the occasion: "I love football! And I love sport! And I want it for everybody! Those very wealthy clubs in the Premiership, pay your 5 per cent so we've got grassroots football for everybody!"

The crowd likes it. Corbyn looks out on thousands of hands raised above heads, clapping. This is going well.

"And it's also about young people and music," he continues.

Some way back in the crowd on the right-hand side a chant has started. It is just a few singing at first, but it spreads like wildfire. Soon it is audible from the stage.

Corbyn is still speaking. "In every child..."-he repeats himself, competing with the noise and glancing to the origin of the chant- "in every child there's imagination and there's hope, and tha..."

His speech stumbles. The chant is louder. The whole front section of the crowd has joined in. "... and so what I want," Corbyn persists, "is every school... every school... to have the money for every child to earn... learn... musical instruments." 
They are not listening to him. The chant is drowning him out. Corbyn stops speaking. It is difficult for him to tell from the stage what they are singing. He thinks they might be having a go at him. This could be a disaster. "I' $m$ looking at these guys chanting," Corbyn will later recall, "and I realise they're smiling. So I paused and realised what they were chanting."

The melody is familiar. It is the White Stripes song 'Seven Nation Army', a tune appropriated by fans in football stadiums around the world. But it has never before been sung with these words.

"Ohhhh, Je-re-my Corrr-byn."

As it dawns on him that they are singing his name, Corbyn feels "quite moved." For 20 seconds he says nothing as the chant envelops the stadium, getting louder and louder, gaining rhythm as people start clapping along. Sections of the crowd are jumping up and down as they sing it. Some are perched on others' shoulders, arms stretched up to the heavens as they belt it out. Something magical is happening. From the left to the right, at the front and even right back at the bar, Prenton Park pays musical tribute to the politician who has come to speak to them.

To the side of the stage, the staff accompanying Corbyn cannot stop laughing. They think it is "absolutely amazing".

...By the time Corbyn leaves the stage, footage of the crowd's reaction is already setting social media alight. (Nunns 2018, pp. 287-288).

Performances require stages, and since most of the legacy media were hostile to Corbyn, the campaign turned to two other platforms as alternative means of symbolic production: rallies and social media. This section will explore each in turn.

Given his history of activist politics, Corbyn was in his essence at rallies, far more so than at the dispatch box in parliament. His politics had been forged within movements so he understood the potent emotional energy that assembled crowds could generate. During the election campaign he spoke at over one hundred rallies and public events, bringing the drama and passion of street politics into the mainstream civil-democratic ritual. His long history of addressing rallies not only guaranteed a firm foundation of support at such events, but also meant that he had in effect conducted a thirty-year audition for the performances he was to deliver during the election campaign. He 'had spent decades learning which lines worked with his target audience' (Shipman 2017, p. 524). What Corbyn had acquired in this process, and what May evidently lacked, was not epistemic knowledge that can be revealed through focus groups, easily codified, and taught by skilful media trainers, but practical knowledge, gained through action and experience (Bourdieu 1979, pp. 466-484; Scott 1998, pp. 309-342). As we shall see, his relaxed, sometimes jokey, typically indignant manner at these rallies provided a stark contrast to May's awkward, somewhat passionless appearances at the Conservatives' far more stage-managed events. The rallies were also spectacular in their scale, unprecedented during a British election campaign, even in Foot's era. Whatever their representativeness (critics insisted that they bore no real relation to his actual national support) their scale offered powerful 
stagecraft, providing formidable images that undercut the dominant media narrative of impending doom.

However, it was not merely the image producing capacity of the rallies that made them important. The physical co-presence of attendees was also key. The assembly of bodies in a single place allowed for the 'regulated commotion' necessary to produce 'collective effervescence' (Durkheim 1995 [1912], p. 218). Even in the so-called 'digital age', this 'emotional energy' (Collins 2005) that crowds are able to conjure and disperse is key to enthusing groups around an electoral programme. Moreover, since such collective enthusiasm circulates back and forth between performer and audience, these events likely buoyed Corbyn's personal confidence too, in a scenario where the size of his inevitable failure was the only mainstream political talking point. Rallies provided possibilities for what Alexander (2004) calls 'fusion' in the here-and-now, in ways that are far more difficult to achieve in mediated public performances (Alexander 2011, p. 19). Of course, such face-to-face contact can only reach an extremely limited self-selected subsample of the voting public, but the recording, live-streaming, and sharing of these ritual events helped disperse the collective enthusiasm well beyond those attending in person.

As the previous section suggested, meaning is established in a relational manner, and the strengths of one performance are magnified when juxtaposed against the weaknesses of another. As we also saw, those cultural workers responsible for organising the Conservative campaign were savvy to this fact and had consciously chosen to frame the election in a presidential manner around the 'strong and stable' figure of Theresa May and-as the Conservatives' Campaign Manager himself put it-to 'take every opportunity to contrast her with Jeremy Corbyn' (Crosby 2017). 'Theresa's Team' replaced the words 'Conservative Party' in placards and other campaign material (Deacon 2017), 'Theresa May’s Conservatives' featured repeatedly in the manifesto headings (Conservatives 2017d, pp. 12, 30, 48, 62, 76). A clear effort was underway to narrow the spotlight upon May alone and provoke the audience to compare her as a carrier of robust security, to Corbyn as a symbol of the opposite. The intentions of stage directors, however, are constrained by the skills of the actors they direct, and May turned out to be a shoddy performer of the attributes she had been cast to embody.

The 'Strong and Stable' slogan was awkwardly and unnaturally squeezed into strained interviews at every available opportunity, and responses were delivered as though she was recalling what she had been directed to say, rather than speaking from natural conviction and belief. Her increasingly robotic performances quickly earnt her the title of 'Maybot' (Crace 2017), whilst the social care U-turn provoked a widely circulated inversion of the 'Strong and Stable' slogan, most famously raised in an excruciating press conference in which a Chanel 4 journalist, Michael Crick, asked her 'doesn't this show you are Weak and Wobbly, not Strong and Stable?'. All this spoiled the possibility of the audience-electorate suspending their disbelief and investing faith in the content of her communications.

May's wooden performances undercut the intended campaign message and failed to evoke the emotions necessary to inspire political action, but so too did the stagecraft of her campaign events. When May was to speak, Tory activists, typically suited, neatly arranged, and holding identical placards, were invited in advance to 
high-security, tightly controlled events, whilst local community members were kept ignorant that she would appear or else excluded via invitation-only rules. This was a very different approach to audience engagement to that described in the vignette that began this section. The predictability of the events left them symbolically sterile and emotionally empty. Journalists were often lined up to ask questions, and accused May's aides of advanced clearing of their content (Crick 2017). Event locations were listed under different purposes to avoid drawing attention to May's presence, such as a rural Aberdeenshire village hall, which was booked as a 'children's party' for her arrival (Bloom 2017; Dearden and Peck 2017). When May visited a factory in Cornwall, local journalists claimed they were forbidden from filming her walking around it, vetted for the questions they would ask, and eventually tweeted images of themselves having been locked away in a room together (Horton 2017; Sharman 2017). On a dramatic level, risk inevitably heightens excitement, explaining the well-established thrills derived from live performances or the 'cliff-hanger' plot device. Audiences are aroused when actors are forced to confront apparently unpredictable or out-of-control scenarios. Over-controlling for risk threatens to render performances insipid. Audiences turn off and they turn away. Entering the election campaign on such poor polling scores meant that Labour could perhaps entertain more risk than their opponents. Following an earlier failed coup attempt, internal party critics saw the election as a second opportunity to get rid of Corbyn as leader. They therefore offered his supporters relative freedom to bury themselves under what they believed would be their radical miscalculations (providing a feasible motivation for the manifesto leak discussed above). Overall, however, it was the insurgent, populist, movement-style ethos of Labour's campaign that lent itself to confronting risk in a manner that the Conservatives' did not.

In democratic societies, legitimate power is not acquired through coronation, but is 'a privilege that must be campaigned for' (Alexander 2012, p. 7). General Elections can be understood as national ritual events, in which liminality looms large. They are national because all eligible citizens can vote and so the drama unfolds in front of a national audience. They are liminal because they break order for the purpose of restoring it, in changed or unchanged form. Liminality, as Turner demonstrated, provides for both the reproduction of social order, but also for its transformation (Turner 1969; Wagner-Pacifici 1986; Morgan 2020a). In the UK, the initial structure of parliamentary representation is broken when an election is triggered, parliament is 'dissolved', and political society moves into antistructure. In this anti-structural state, representative democracy is held in abeyance. Parliament no longer exists, and MPs no longer hold office, and so they 'elude or slip through the network of classifications that normally locate states and positions in cultural space' (Turner 1966, p. 95). Liminality in the election cycle therefore introduces uncertainty, and MPs must present themselves to the public in order to be reconfirmed as valid representatives. Failure to engage in this ritual of public scrutiny can hold dire consequences. Those who transgress the established ritual norms jeopardise their successful transition through the rite of passage. The excessive control of the Conservative's campaigning events allowed the Corbyn team to accuse May of 'hiding from the public' and therefore frame her as breaking with the ritualistic necessity for a leader seeking reconfirmation 
to expose themselves to the scrutiny of the people. Speaking explicitly about this contravention of the norms of civil society's democratic rituals, Corbyn accused May of 'showing contempt for the public'. 'She won't take part in TV debates and she won't talk to voters.' Highlighting the semiotic contradiction that she displayed, Corbyn argued that 'refusing to debate Labour in this election isn't a sign of strength, it's a sign of weakness. What is she afraid of?' (quoted in Elgot and Khomami 2017).

This insulation from public scrutiny culminated in May's steadfast refusal to engage Corbyn directly in a BBC broadcast Party Leaders' debate just over a week before the final poll. Seamus Milne, Labour's Director of Strategy and Communications, seemingly aware of May's weakness as a public performer, had briefed the NEC at the outset of the campaign that Labour should "push for head-to-head TV debates' (Milne 2017). It was widely rumoured that Corbyn would not be taking part without the Prime Minister's presence, but in the early afternoon of the broadcast it was announced that he would attend. May stood by her refusal and sent the Home Secretary, Amber Rudd, to stand in for her, a move that was widely criticised as callous after it was revealed that Rudd's father had died just 48 hours earlier. Rudd's presence highlighted May's absence, which in turn brought into relief May's transgression of the norms of the democratic rite inherent in her role as 'liminal persona' (Turner 1964, p. 5). When pressed by a journalist as to why she was not attending, she responded that Corbyn was "paying far more attention to how many television appearances he's doing. He ought to be paying a little more attention to thinking about Brexit negotiations — that's what I'm doing' (in Merrick 2017). This was a less then convincing response in the middle of an election campaign, given that Corbyn was not involved in negotiating Brexit, and May herself had unilaterally decided to call the snap election. Yet again, the meanings it projected were far from the 'strong and stable' ones that her cultural workers had intended her to carry.

Social media provided the second alternative stage on which the Corbyn narrative played out. Whilst those who attended the rallies were energised directly from being part of an effervescing collective, their emotional power ended up reverberating beyond these physical events, through images and videos being shared and interacted with online, initiating a cascade of 'interaction ritual chains' (Collins 2005).

UK media ownership is highly concentrated, and oligopolisation is particularly pronounced for national newspapers with $71 \%$ of circulation owned by just three companies (MRC 2015). Rather than court the moguls, Corbyn had openly stated that a future Labour government would challenge this concentration on the basis that it distorted the democratic process (Labour 2017, p. 97). In line with the general metanarrative described above and following a particularly imaginative story claiming Corbyn had been a Czech spy during the 1980s, Corbyn made a promise to the giant media corporations that 'change is coming'.

Change had in many ways already come. Legacy media were steadily declining with the rise of social media platforms as alternative news sources. The morning following the Conservative victory in the 1992 General Election, Britain's highest-circulation newspaper-Rupert Murdoch's The Sun-congratulated itself for its unstinting attacks on Labour during the campaign with the famous frontpage headline 'It's The Sun Wot Won It'. By contrast, following the 2017 election, 
Corbyn, was able to make the following remarks about the second highest-circulation national newspaper: 'One paper devoted 14 pages to attacking the Labour Party and the following day our vote went up nearly $10 \%$. Never have so many trees died in vain. The British people saw right through it. So, this is a message to The Daily Mail's editor-next time, please make it 28 pages' (in Buchan 2017). Remarkably, it is estimated that $30 \%$ of Sun readers and $17 \%$ of Daily Mail readers actually voted for Labour in the 2017 election (YouGov 2017b), and what Corbyn's speech picked up on, and what the poll arguably indicated, was the emergence of a 'cry wolf' effect. The absurdity of the press attacks preceding the election-including the Daily Mail reporting that Corbyn had welcomed the prospect of an asteroid 'wiping out' humanity (McTague 2015), and The Times (a 'newspaper of record') casually referring to Corbyn's 'Chairmen Mao-style bicycle' (Coates 2015) — appear to have provoked a growing distrust in their messaging. This reading is corroborated by the revelation that spikes in recruitment to Momentum regularly followed negative but highly publicised media stories (Khomami 2018).

Corbyn's refusal to flirt with the powerful purveyors of information nevertheless presented a major challenge since in a national drama such as a General Election, political narratives need to be propagated to vast, internally segmented populations. In this context, mediation becomes unavoidable. Labour may have benefited from the introduction of so-called 'purdah' rules, which prohibit civil servants from pronouncements that could affect party support during an election. Nevertheless, even with such rules in place, media analysis reveals that the print media were not only far more negative towards Labour than the Conservatives during the election (Deacon et al. 2017), but also that the scene had been set well in advance via systematic bias, misrepresentation of views, and active hostility towards Corbyn since his 2015 leadership bid was announced (Cammaerts et al. 2016; Cartright 2015; Freedman and Schlosberg 2016). Legacy media were failing in their role as communicative institutions of the British civil sphere, so the Corbyn team sought an alternative means of symbolic production, capable of circumventing the mainstream narrative, and found it in the participative, user-generated hubbub of online social media.

The Corbyn campaign team realised that the punchy, rapidly consumable format of social media messages had a far greater 'carrying capacity' than traditional newspaper articles (Hilgartner and Bosk 1988), and especially so when they included multimedia. Moreover, they provided a means through which the party leader could talk directly to the electorate in a manner that chimed with the populist stylisation of the campaign. This mattered particularly for younger audiences (Young 2018, pp. 30-43) who are especially likely to source their news from social media (Ofcom 2018), and who have long been underrepresented in voter registration and turnout. Corbyn's endorsement by many grime (a genre of British urban music) artists provided an additional bridge to youth voters (Hancox 2018, pp. 271-294). The online \#Grime4Corbyn movement, for instance, encouraged youth voter registration by exchanging free tickets to a secret rave for having signed up to vote (Duggins 2017).

During the election, influential social media adepts acted independently of the central campaign team as online outriders. Combined with organisations sympathetic to many of the reforms that Labour were promising, this created what Dommett and Temple have termed a 'satellite campaign', 'originating beyond party 
structures and control' (2018, p. 195). The actors involved in this campaignwhether in the form of individual 'citizen-initiated' or organisational 'democratic intermediary' accounts - enjoyed large followings capable of reaching a greater audience diversity than the official campaign accounts alone. Whilst operating independently from the top-down campaign, some of these accounts were loosely but informally connected to the official campaign through e.g. shared WhatsApp groups, allowing them to raise awareness of particular policies as they were announced and redefine the news agenda away from that shaped by the legacy media. They were also able to produce direct anti-Tory attack lines in ways that the official campaign was constrained from doing, mainly because Corbyn himself had personally stated that it was essential for the official campaign to remain positive. This 'satellite campaign' ecosystem also included rebuttal accounts that played a crucial defensive role in designing attention-grabbing memes that countered what they saw as misinformation and spin, holding Tory politicians and hostile journalists to account through various forms of fact-checking in ways that would have been impossible prior to the rise of widespread digital communication technologies.

As well as producing reactive messaging and fleeting political coalitions that often arose and dissipated very rapidly in response to particular issues or events, swarming around topical hashtags and commenting upon the drama in real-time, the unofficial use of social media also helped consolidate a more durable emergent political common sense (Gramsci 1971, pp. 423, 330f). Building on Gramsci, the significance of establishing such doxic political understandings has been emphasised by Woodly (2015) in her account of how social movements typically succeed by bringing issues to a state of 'political acceptance'. This refers not to movement's political positions being accepted as correct, but rather to their being considered legitimate for discussion in mainstream political discourse. She argues that movements succeed less through direct policy victories, but more through changing the content and terrain of acceptable and relevant political debate. The more that the funding of Social Care, for instance, could be developed into a central issue in online social media, the more it became a legitimate issue to which the government were forced to respond in mainstream media forums.

In addition to these modes of agenda setting and political persuasion, there were also more direct and practical effects of the use of the new media environment, such as in voter registration drives, and Momentum's 'My Nearest Marginal' app, that allowed users to find their nearest marginal seat and organise carpooling to help canvass in that area.

Via online activity, the broader movement around the Labour campaign was therefore not only able to establish a radically different narrative to that being established in print and over the airwaves, but also to subtly shape what was happening in these more traditional media too. However, the significance of social media was not only to be found in its potential to spread collective enthusiasm, its superior 'carrying capacity', or its ability to circumvent and shape the legacy narrative. It was also that it 'interpellated' (Althusser 1971, p. 121) its audience as not simply passive receivers, but also as actors in generating, propagating, interpreting, and reinterpreting its message. Since social media are participative, rather than merely consumptive, they served to extend an invitation into the drama, mobilising 'adherents' into 
'constituents' (McCarthy and Zald 1977). The political narrative, in other words, aspired to go beyond being simply an informational projection from a distant campaign team, to becoming a collectively constructed project, within which supporters themselves — online and offline-could become actors in the unfolding story. This harmonised with the overall participative ethos of Corbynism more generally, the leadership's experimentations with devising policy through crowdsourcing ideas, and the long-held concern with democratising internal party structures.

Whilst the Tories also invested heavily in social media, the weakness of their approach lay in the relative absence of such a participative ethos, alongside their neglect in providing either a hopeful message or a sense of shared identity for those engaging with them. The most heavily pushed social media videos from the Conservatives contained carefully edited footage of extracts from speeches given by three of Labour's top figures-Corbyn, McDonnell, and Abbott-doused in dark post-production lighting and with foreboding background music, warning that these ghouls might be on the brink of power (Conservatives 2017a, b, c). In tune with most of the legacy media's messaging, this kind of fear-inducing approach worked on the 'avoidance motivational system', rather than the 'approach motivational system' (Castells 2012, pp. 13-14), which whilst potentially effective in convincing individuals not to do something, is less successful in mobilising participants to act. Reflecting back on the election, one social media advisor for the Conservative campaign remarked that it should have been 'about building a movement, and social media can provide the glue for people to bond together. If your strategy is to poke holes in the other side you don't evoke that emotion of togetherness which is an important factor in getting people to vote' (Singh, in Booth and Hern 2017).

One way of characterising the difference in participation between the two online campaigns is that the Tories' was based more around the traditional logic of 'collective action', whereby digital media is conceived as merely one resource among others to propagate a campaigning message (in this instance, a largely negative one), and not a medium that - through its unique nature-can fundamentally change the dynamics of collective action (Bennett and Segerberg 2012). Conversely, the Corbyn campaign team-partly on the back of their experience during the Corbyn-forLeader campaign, and certainly with the help of the campaigning group Momentum (an organisation with no equivalent counterpart on the Conservative side)—realised that digital media held the capacity to transform the logic of shared action so as to become self-organising in the absence of any formal institutional command. This meant that they designed material not simply to be consumed or to prevent people from voting a particular way, but also to be shared, discussed, interacted with, and commented upon in a personalised way, with the ultimate goal of activating those that engaged. This was the logic of 'connective action'. The campaign team learnt that the enthusiasm that social media can generate was stultified when overly controlled and came into its own when operating at a distance from central command (Nunns 2018, p. 114). As with the rallies, the relinquishing of control over social media opened up risk but also allowed for 'connective action' through 'personalised content sharing' that distributed the subjectivity of campaigning well beyond the social media team, party members, or conventional activists. 
Whilst Labour did complement this organic use of social media with paid-for digital advertising, research suggests that the former promote greater confidence in content. Rather than mere exposure to a message, it is when messages are given credence through being shared and positively interacted with by trusted nodes in one's social media network, that political opinions are more likely to be shaped (Sterrett et al. 2018; Shirky 2008). Moreover, consumers of social media are more likely to be swayed by messages issuing from those third parties (e.g. single-issue campaign groups, media commentators, NGOs, etc.) that composed the 'satellite campaign', rather than directly from political parties themselves.

Where the rallies mostly achieved ritualistic fusion in the more familiar and traditional ways of expressing mechanical solidarity and re-solidifying a shared political 'conscience collective', social media allowed for more individually tailored expressions of 'weak-tie' organic solidarity, allowing a complex, horizontal and multifaceted online leviathan to rise up. The Corbyn campaign therefore capitalised on both 'collective' and 'connective' forms of action (Bennett and Segerberg 2012) relying upon peer trust and the activation of emotions of hope, as opposed to fear. The results were impressive: pro-Labour sentiments dominated the Twitter conversation (Cram et al. 2017) and whilst the Conservatives spent $£ 2.1$ million on Facebook advertising, Labour's spend of $£ 0.5$ million resulted in wider and more favourable shares. During the campaign period, likes for Corbyn's Facebook page rose from already high figures by more than 35\%, and those for the Labour Party by $71 \%$, whilst the equivalent figures for Theresa May and the Conservatives were $21 \%$ and $11 \%$ respectively (Walsh 2017). Out of the top one hundred most shared online stories during the election, only five were pro-Conservative (Mayhew 2017). Momentum spent a mere $£ 2000$ on Facebook advertising, but due to the organic and participative nature of their content, and the connective logic through which it was engaged with and distributed, almost a quarter of all UK Facebook users saw one of their videos in the final week of the campaign.

Similarly to the 'movements of the squares' that blossomed in the wake of the Arab Spring, within which digitally networked action was periodically reinforced by face-to-face meetings in public space (Bennett and Segerberg 2012, p. 744; Castells 2012, p. 261), the digital connections taking place around the Corbyn movement were likewise bolstered by the 'synergistic networks' that gathered together physically in town halls, community centres, and parks to organise, share experiences, and hone their messages. The embodied rallies fed the online media with content, and the online media spread the affect generated in these face-to-face rituals.

These alternative stages also became subject to code-rerouting like so many of the other expressive signifiers that were debated within the election. The rallies were recoded as anti-civil by labelling them as on the one hand, demagogic spectacles, and on the other, as insignificant 'rent-a-crowd' gatherings, bearing no representative relation to actual national sentiments. Independent, Corbyn-sympathising media organisations with a strong online presence were branded untrustworthy, as propagating 'fake news', and social media activists were accused of initiating online 
bullying and intimidation. ${ }^{13}$ Following the election, May claimed that 'Russian bots' had manipulated online messaging. The very characteristics of social media that had been coded as civil by Corbyn's supporters-its openness, its inclusivity, and its apparent autonomy from power or money, were recoded as anti-civil by its critics. Social media was presented as a pressing threat to the norms of civil debate; polarising rhetoric, rather than steering it towards polite disagreement and necessary compromise. Theresa May later ordered a legal review into online behaviour and at its announcement drew upon the language of the civil sphere in suggesting that 'our public debate today is coarsening ... it is becoming harder to disagree, without also demeaning opposing viewpoints in the process' (quoted in Stewart 2018).

\section{Conclusion}

It hardly needs stating that many factors beyond those explored above influenced the course of the 2017 General Election. This paper has simply argued that given the lack of any sudden material shifts explaining the striking rise in Labour's support that occurred within the short campaign period, cultural work, and the nonmaterial coding structure within which this work took place, ought to be included within any holistic explanation. It has tried to stress, however, that the agents of this symbolic action did not always bring about the consequences they intended, and that this occurred for various reasons.

Firstly, compelling political narratives take propositional forms that project a partially unresolved plot from the past through the present, forward into the future. Unresolved plots that include ellipses and undetermined (rather than foregone) conclusions can activate audience participation in the hope that their activity will bring about the ending of the story they wish for. When such narratives are projected in a persuasive manner, they hold the power to interpellate audience members as political actors, rather than passive consumers of politics. Such newly activated audience members are not simply convinced to vote one way or another but are inspired to convince others to do so too. 'Adherents' are transformed into 'constituents' (McCarthy and Zald 1977, pp. 1221-1223), the size of one's 'performance team' is increased, and with it, the extent of the ideal and material resources at one's disposal. ${ }^{14}$ Judged on this basis, the Conservative campaign fell short. The campaign

\footnotetext{
13 Research by Amnesty International later demonstrated that the UK's first black female MP, Shadow Home Secretary, and staunch Corbyn ally, Dianne Abbott, had in fact received a staggering $45.14 \%$ of all abusive tweets sent to female MPs in the run-up to the election (Stambolieva 2017).

14 It is widely agreed that Labour's 'ground game' outshone the Conservatives' due its vastly expanded membership since Corbyn took over as leader, providing four times the number of activists to help knock on doors and proselytize the message. The newly enlarged membership also brought in money through subscriptions (to the tune of $£ 16$ million, compared to $£ 1$ million for the Tories (Syals 2018)), and a great number of energised individuals also volunteered time and donated money. Labour raised around $£ 5$ million in small donations from the public during the election campaign, receiving over 100,000 online donations, with the average size being just $£ 22$. The Tories, by contrast, raised $£ 5.5$ million from just 49 large donations (Ashmore 2017). These disparities in funding sources of course held important symbolic weight too, corroborating the 'for the many, not the few' slogan, and chiming with the participative spirit of the campaign narrative.
} 
took an oppositional approach that projected messages aimed at dissuading audience members from voting Labour, rather than inspiring them to campaign for the Conservatives. The 'continuity and stability' framing provided no sense of an alternative national future. Likewise, the initial presentation of the election as a fait accompli provided no ambiguity or unresolved tension that a future Conservative government, let alone an inspired and engaged electorate, might overcome. In contrast to the Labour Party's overriding narrative, it was ultimately a proposition of paralysis rather than a dynamic invitation capable of drawing an animated audience into the national story.

Secondly, the intended coding and narrative weaving of cultural workers invariably operates within prevailing culture structures that are capable of both aiding and impeding this work. For this reason, such symbolic structures ought to be considered relatively autonomous in wielding their own independent influence upon meaning outcomes. Whilst, for instance, Tory counter-coding may have been successful in establishing fear around the prospect of a Corbyn-led government, it simultaneously reinforced the central Labour narrative that the party would indeed provide a break from the status quo. Formal semiotic coding foreclosed the possibility of meaningfully arguing that Labour risked both a radical and dangerous shift in direction for the country, and at the same time that what they proposed presented no political alternative.

Thirdly, what I have called 'code-rerouting' can often take place in contingent and contentious political dramas, whereby signifiers are rerouted to correspond to alternative signifieds. Such processes may be thought of as similar to what LeviStrauss described as formal 'transformation' relationships in his explanation of how the generalised deep structures underlying world myth expressed themselves with diverse empirical variation (1967b, pp. 1-48; Descola 2016). The signifiers of Corbyn's dress sense, for instance, were rerouted away from anti-civil signifieds, e.g. of lack of respect for high office, towards civil ones, e.g. of trust and the autonomy of motives, achieved through alignment with the broader Labour metanarrative's break from the preceding era of insincere spin politics. An important aspect of such transformations is that the variation in correspondence between a particular signifier and its associated signified does not disturb the structure of the civil/anti-civil relationship itself. Sometimes this rerouting is consciously intended by political actors, e.g. through public relations exercises, but at other times it results from the laws of homology and opposition inherent in meaning itself. Mostly, it is the outcome of a combination of both: culture workers producing partially intended results, capitalising on lucky outcomes, or attempting to mitigate unforeseen and unwelcome meanings.

Fourthly, in order to come off successfully, political dramas require higher standards of experiential commensurability than fiction dramas. Resonant political performances not only need convincing actors, compelling plots, appropriate stages, and so on, but they also need to establish salience with their audience's experiences. Since experiences are themselves shaped (though never determined) by material processes, it is here that the 'hard' material realities of a political climate-closure of community centres, rising street crime, prolonged hospital waiting lists-meet up with their symbolic renderings. Though it was referred to briefly in the Introduction, 
this essential aspect of any complete explanation has been intentionally underplayed in the preceding analysis. This is firstly, because its significance is typically taken for granted to such an extent that it tends to occupy the exclusive focus of conventional political explanation, and secondly, because such explanations too often treat experience as a given, reading it directly off material factors. The purpose of this analysis has not simply been to fill explanatory gaps left behind by such conventional analyses, but to defend the position that the apparently unmediated instrumental or material features of a political environment-even such apparently 'hard' realities as acts of terror-are, when transferred over into experience, in fact invariably shot through with all manner of meaning-making.

Fifthly, the paper has argued that excessive efforts towards controlling for risks in political dramas can, ironically, often end up inviting them. Risk, and a sense of spontaneity in performance grips audiences, and apparent over-scripting, rehearsing, or stage-managing renders performances zestless and uninspiring, threatening their ability to arouse the emotions that feed political action. What's more, the wellestablished norms of democratic rituals require those participants seeking public office to expose themselves to the specific risks inherent in the scrutiny of the voting public during a campaign. Whilst avoiding doing so can insulate a candidate from immediate risks, it may end up provoking graver ones in the longer term through the flouting of norms it entails. Candidates who do not adhere to this expectation of liminal personae - as illustrated by May's overly controlled campaigning events and her refusal to debate other party leaders on live TV-may avoid the immediate uncertainty inherent in public confrontations, only to reencounter a more profound one in the ballot box. Put in the language of Civil Sphere theory, it might be said that the avoidance of direct risk at the subjective level of the communicative institution of public opinion, only defers an even greater risk to the more objective and constraining level of the regulative institution of the election process (Alexander 2006, pp. 69-151).

A final related and critical feature of social performance if absent, can vitiate its success, and if present, can lead audiences to forgive other less significant weaknesses: coherence. Coherence is important across all of cultural pragmatic's 'elements of social performance' (Alexander 2004), but in political struggles that involve a competition for the premiership of a polity, the perceived internal and external coherence of the main contenders becomes paramount and subject to extensive democratic scrutiny. Judgements of such coherence are logical, moral, and even emotional. Performances need to be seen to hang together over time and place in logically sequential and coherent ways, actors' public projections need to be seen to correspond to what is known of their private lives, surface appearance needs to be congruent with perceptions of a character's deeper motives and feelings about their inner 'nature', and their individuality need to be seen as compatible with their iconicity. Since many agents are necessarily involved in producing national dramas, apparent coherence also needs to be maintained across these performance teams. One weak link, such as one poor actor, one incompetent director, or one inappropriate choice of stage, can undermine the whole intended projection. In this manner, the overarching coding of the Tory campaign was performatively undermined on 
repeated occasions by Theresa May's ineffectiveness in pulling off the 'strength and stability' that she had been directed to carry.

To conclude, it is worth reiterating that whatever content cultural workers strove to array on either the pure or polluted, sacred or profane side of the binaries of civil society, and whether or not this work in fact achieved its intended outcomes, the formal structure itself-as civil sphere theory would suggest (Alexander 2006, pp. 646-648)—was never subject to contestation (Mouffe 2000). Corbyn's Manchester Speech, for instance, located the bombing within a wider political field that saw the 'blowback' from foreign policy adventures and the consequences of scrimping on domestic security as salient contextual features in a rounded political understanding of the event. The question to be asked of this performance was whether it should be coded as civil in its providing a candid account of the incident that might help ensure such events were not repeated, or whether it should be coded as anti-civil, in its distracting from the moral condemnation that was necessary of such a barbarous act. The status of civility as a good to be sought, and anti-civility as an evil to be banished, formed the consensual architecture within which the coding dispute unfolded. Hegemonic struggles over solidifying one's own coding as legitimate and natural, and propagating one's own narratives as authoritative, appear to orient themselves towards the same underlying culture structures as the counter-coding and counter-narrativising they confront. In this sense, the sign system of political discourse presents itself as akin to a language in being relatively durable and implicitly conservative. Whether or not this system is universal (Lévi-Strauss 1967a, cf. Douglas 1972, p. 62; Alexander 2015, pp. 178-180), it does appear that the deeper one goes, and the more simplified and generalised the nesting structure, the more resistant it is to change, and therefore the more taken-for-granted and less subject to question its distinctions. Even if conflicting political cultures do often tend to talk past one another, if these more profound meaning structures were not broadly agreed upon, comprehensible meaning itself, and in particular the ability to communicate symbolic information across cultural divides, would eventually break down.

Acknowledgements An earlier version of this article was presented at Yale University's Center for Cultural Sociology workshop in April 2019. I would like to thank participants of that workshop for their generous and challenging comments, in particular, Anne Taylor, Mervyn Horgan, Vanessa Bitner, and Anne Marie Champagne, as well as the directors of that workshop, Jeffrey Alexander and Philip Smith, and its co-convener, Natalie Aviles, for valuable feedback and the invitation to present. Thanks are also due to the three anonymous AJCS reviewers who provided extremely useful comments in revising the paper, and to Rob Scott for kindly granting permission to reproduce the image of Corbyn protesting apartheid.

Funding This study did not receive any funding.

\section{Compliance with ethical standards}

Conflict of interest The author declares that they have no conflict of interest. 


\section{References}

Acevedo, G.A., J. Ordner, and M. Thompson. 2010. Narrative Inversion as a Tactical Framing Device: The Ideological Origins of the Nation of Islam. Narrative Inquiry. 20 (1): 124-152.

Alexander, J.C. 2003. Watergate as Democratic Ritual. In The Meanings of Social Life, 155-177. Oxford: Oxford University Press.

Alexander, J.C. 2004. Cultural Pragmatics: Social Performance Between Ritual and Strategy. Sociological Theory 22 (4): 527-573.

Alexander, J.C. 2006. The Civil Sphere. Oxford: Oxford University Press.

Alexander, J.C. 2010. The Performance of Politics: Obama's Victory and the Democratic Struggle for Power. New York: Oxford University Press.

Alexander, J. 2012. Trauma: A Social Theory. Cambridge: Polity Press.

Alexander, J.C. 2015. Nine Theses of The Civil Sphere. In Solidarity, Justice, and Incorporation: Thinking through The Civil Sphere, ed. P. Kivisto and G. Sciortino. Oxford: OUP.

Alexander, J.C., and P. Smith. 1993. The Discourse of American Civil Society: A New Proposal for Cultural Studies. Theory and Society 22 (2): 151-207.

Alexander, J.C., and P. Smith. 2003. The Strong Program in Cultural Sociology: Elements of a Structural Hermeneutics. In The Meanings of Social Life, ed. J.C. Alexander, 11-26. Oxford: Oxford University Press.

Ali, T. 2018. The Extreme Centre: A Second Warning. London: Verso Books.

Allen, N., and J. Bartle, eds. 2018. None Past the Post: Britain at the Polls, 2017. Manchester: Manchester University Press.

Althusser, L. 1971. Ideology and Ideological State Apparatuses. In Lenin and Philosophy and other Essays, 121-176. New York: Monthly Review Press.

Ashmore, J. 2017, June 2. EXCL: Tories Rake in over $£ 5 \mathrm{~m}$ from Just 49 Individual Donors Under Theresa May. Politics Home.

Austin, J.L. 1955. How to Do Things with Words: The William James Lectures, delivered at Harvard University. Oxford: Clarendon Press.

Baert, P. 1991. Unintended Consequences: A Typology and Examples. International Sociology 6 (2): 201-210.

Baiocchi, G. 2012. Cultural Sociology and Civil Society in a World of Flows: Recapturing Ambiguity, Hybridity and the Political. In The Oxford Handbook of Cultural Sociology, ed. J. Alexander, R. Jacobs, and P. Smith, 232-256. New York: Oxford University Press.

Balls, E. 2015, March 1. BBC Radio 4 - Today, 19/03/2015. BBC. https://www.bbc.co.uk/progr ammes/b055j9rs.

Barthes, R. 1993. Introduction to the Structural Analysis of Narratives. In Image Music Text, 79-124. London: Fontana Press.

Bartle, J. 2018. Why the Conservatives Lost Their Majority-But Still Won. In None Past the Post: Britain at the Polls 2017. Manchester: Manchester University Press.

BBC. 1984. Scruffy Jeremy Corbyn Winds Up Tories - BBC Newsnight. https://www.youtube.com/ watch?v=wZsYvkTw4Rg.

BBC. 2015, June 3. Labour Leadership: Jeremy Corbyn Enters Race. https://www.bbc.com/news/ukpolitics-33000155.

BBC. 2016, February 24. Cameron 'Put on a Proper Suit' Jibe at Corbyn at PMQs. https://www.bbc. com/news/uk-politics-35651000.

Beckett, A. 2017. How the Tory election machine fell apart. The Guardian. Mon 26th June.

Benford, R.D., and D.A. Snow. 2000. Framing Processes and Social Movements: An Overview and Assessment. Annual Review of Sociology 26: 611-639.

Bennett, W.L., and A. Segerberg. 2012. The logic of Connective Action. Information, Communication \& Society 15 (5): 739-768.

Bloom, D. 2017. How stage-managed are Theresa May's General Election rallies? Your full depressing guide to the Tory campaign. Daily Mirror, 9 May, 2017.

Boffey, D. 2015. David Cameron blames 'brain fade' for getting his football team wrong. The Guardian.

Bolton, M., and F.H. Pitts. 2018. Corbynism: A Critical Approach. Bingley: Emerald Publishing Limited. 
Bourdieu, P. 1979. Distinction: A Social Critique of the Judgment of Taste. Cambridge MA: Harvard University Press.

Bower, T. 2019. Dangerous Hero: Corbyn's Ruthless Plot for Power. London: William Collins.

Bulman, M. 2017, November 22. The Moment Jeremy Corbyn Lost It with Jeering Tories During Today's Budget.

Burke, K. 1966. Language as Symbolic Action: Essays on Life. Literature and Method: University of California Press.

Cammaerts, B., B. DeCillia, J. Magalhaes, and C. Jimenez-Martinez. 2016. Journalistic Representations of Jeremy Corbyn in the British Press: From Watchdog to Attackdog. London: London School of Economics.

Cartright, A. 2015. Corbyn's First Week: Negative Agenda Setting in the Press (Media Reform Coalition). London: Media Reform Coalition.

Castells, M. 2012. Networks of Outrage and Hope: Social Movements in the Internet Age. Cambridge: Polity Press.

Coates, D. K. Sam. 2015, September 14. Marr is Snubbed for a Day at Church. The Times.

Collier, H. 2017, May 12. May Blasts Corbyn's 'Chaotic' Plans for Economy in Leaked Manifesto. Evening Standard.

Collins, R. 2005. Interaction Ritual Chains. Princeton, NJ: Princeton University Press.

Conservatives. 2017a. On June 9th, this man could be Prime Minister. YouTube video, May 26th, 2017. https://youtu.be/x9Fqdsg6HkQ.

Conservatives. 2017b. Jeremy Corbyn wants this man to run our economy. YouTube video, May 14th, 2017. https://youtu.be/SC9jt9ZMrp0.

Conservatives. 2017c. If Corbyn's team got in, it would be no laughing matter. YouTube video, May 14th, 2017. https://youtu.be/DnG51cWlKmk.

Conservatives. 2017d. The Conservative \& Unionist Party Manifesto, 2017.

Corbyn, J. 2015a. Leader of the Labour Party Acceptance Speech. http://jeremycorbyn.org.uk/artic les/5912/. Accessed 10 April 2019.

Corbyn, J. 2015b. Speech by Jeremy Corbyn to Labour Party Annual Conference 2015. https://www.polic yforum.labour.org.uk/news/speech-by-jeremy-corbyn-to-labour-party-annual-conference-2015.

Corbyn, J. 2017. Jeremy Corbyn Speech. The Labour Party website: https://labour.org.uk/press/jerem y-corbyn-speech-2/. Accessed 10 April 2019.

Cowburn, A. 2017, April 15. Jeremy Corbyn's policy blitz supported by majority of British public, poll says. The Independent.

Cowley, P., and D. Kavanagh. 2018. The British General Election of 2017. London: Palgrave Macmillan.

Cowley, P., and M. Stuart. 2008. Browned Off? Dissension Amongst the Parliamentary Labour Party, 2007-2008: A Data Handbook. Nottingham: ESRC/University of Nottingham.

Crace, J. 2017, July 10. The Making of the Maybot: A Year of Mindless Slogans, U-turns and denials. The Guardian.

Cram, L., Llewellyn, C., Hill, R., \& Magdy, W. 2017. General Election 2017: A Twitter Analysis. arXiv preprint arXiv:1706.02271.

Crick, M. 2017, May 9. [Tweet @MichaelLCrick].

Crosby, L. 2017. 'Election Strategic Note', in Appendix of Shipman T. In Fall Out: A year of Political Mayhem. London: William Collins.

Curtis, C. 2017. How Britain Voted at the 2017 General Election. YouGov, https://yougov.co.uk/topics/ politics/articles-reports/2017/06/13/how-britain-voted-2017-general-election.

Dahlgreen, W. 2016. Approval of Government Cuts at Lowest Level for Years. YouGov. https://yougo v.co.uk/topics/politics/articles-reports/2016/03/16/cuts-approval-budget.

Daily Telegraph. 2017, May 10. Labour has Produced a Fantasy-Land Blueprint for a Socialist Britain. Daily Telegraph.

de Saussure, F. 1893/1915. Course in General Linguistics, ed. C. Bally and A. Riedlinger. London: McGraw-Hill.

Deacon, D., J. Downey, D. Smith, J. Stanyer, and D. Wring. 2017. National News Coverage of the 2017 General Election. Loughborough: Centre for Research in Communications and Culture, Loughborough University.

Dearden, L., and T. Peck. 2017, April 30. Theresa May accused of 'hiding' after election event publicly listed as child's party. The Independent.

Deacon, M. 2017, May 8. The Conservative Party is no More. Now It's Just “Theresa May's Team”. Daily Telegraph. 
Debord, G. 1957. Report on the construction of situations and on the International Situationist Tendency's conditions of organisation and action. In Situationist International Anthology, ed. Ken Knabb, 17-25. Berkeley, CA: Bureau of Public Secrets.

Debord, G. \& Wolman, G. J. (1956). A Users Guide to Détournement. In Complete Cinematic Works: Scripts, Stills, Documents. (trans. Ken Knabb). Oakland, CA: AK Press.

Descola, P. 2016. Transformation Transformed. Hau: Journal of Ethnographic Theory 6 (3): 33-44.

Diani, M. 1992. The Concept of Social Movement. Sociological Review 40 (1): 1-25.

Dommett, K., and L. Temple. 2018. Digital Campaigning: The Rise of Facebook and Satellite Campaigns. Parliamentary Affairs 71: 189-202.

Douglas, M. 1972. Deciphering a Meal. Daedalus 101 (1): 61-81.

Duggins, A. 2017, June 5. 'Stop Saying He's Unelectable!' Grime4Corbyn Movement Moshes for Jeremy. The Guardian.

Durkheim, É. 1995 [1912]. The Elementary Forms of the Religious Life. London: The Free Press.

Electoral Commission. 2017. Electoral Registration Report, July, 2017.

Elgot, J., and N. Khomami. 2017, April 28. Theresa May accused of hiding from public at activist-filled event. The Guardian.

Eyerman, R. 2019. Memory, Trauma, and Identity. London: Palgrave Macmillan.

Fieldhouse, E., and C. Prosser. 2017. The Brexit election? The 2017 General Election in ten charts. Oxford: The British Election Study.

Fielding, S. 2002. The Labour Party: Continuity and Change in the Making of New Labour. Houndmills: Palgrave Macmillan.

Fielding, S. forthcoming. The Labour Party: From Callaghan to Corbyn. Cambridge: Polity Press.

Fisher, S., C. Hanretty, and W. Jennings. 2017. Expert Predictions of the 2017 General Election, 2nd June, 2017, Political Studies Association.

Freedman, D., \& Schlosberg, J. 2016. Jeremy Corbyn, impartiality and media misrepresentation.Open Democracy, 29th July, 2016.

Frye, N. 1957. Anatomy of Criticism: Four Essays. Princeton NJ: Princeton University Press.

Fukuyama, F. 1992. The End of History and the Last Man. London: Penguin.

Ganz, M. 2009. What is Public Narrative: Self, Us \& Now. Working Paper, Harvard Kennedy School of Government.

Garrido, M. 2017. Why the Poor Support Populism: The Politics of Sincerity in Metro Manila. American Journal of Sociology 123 (3): 647-685.

Gauna, A.F. 2018. Populism, Heroism, and Revolution. Chávez's Cultural Performances in Venezuela, 1999-2012. American Journal of Cultural Sociology 6 (1): 37-59.

Gentleman, B.A. 1999, May 13. MP and Wife Split over School. The Guardian.

Giddens, A. 1994. Beyond Left and Right: The Future of Radical Politics. Cambridge: Polity Press.

Goffman, E. 1983. Felicity's Condition. American Journal of Sociology. 89 (1): 1-53.

Goffman, E. 1990 [1959]. The Presentation of Self in Everyday Life. London: Penguin Books.

Gramsci, A. 1971. Selections from Prison Notebooks. New York: International Publishers.

Hannah, S. 2018. A Party with Socialists in It: A History of the Labour Left. London: Pluto Press.

Hancox, D. 2018. Inner City Pressure: The Story of Grime. London: William Collins.

Hattenstone, S. 2015, June 17. Jeremy Corbyn: 'I Don't Do Personal'. The Guardian.

Heath, O., and M. Goodwin. 2017. The 2017 General Election, Brexit and the Return to Two-Party Politics: An Aggregate-Level Analysis of the Result. The Political Quarterly 88 (3): 345-358.

Hebdige, D. 1979. Subculture: The Meaning of Style. London: Routledge.

Hilgartner, S., and C. Bosk. 1988. The Rise \& Fall of Social Problems: A Public Arenas Model. American Journal of Sociology 94 (1): 53-78.

Hochschild, A.R. 2016. Strangers in Their Own Land: Anger and Mourning on the American Right. New York: The New Press.

Horton, H. 2017, May 2. Local Journalists Furious After Theresa May Shuts Them Out of Cornwall Factory Visit. Daily Telegraph.

Howell, S. 2018. Game Changer: Eight Weeks That Transformed British Politics. Cardiff: Accent Press.

Hussain, M. 2010. Islington North MP Jeremy Corbyn is the Country's Lowest Expenses Claimer. Islington Gazette, 8 December 2010.

Jones, O. 2020. This Land: The Story of a Movement. London: Allen Lane.

Joose, P. 2018. Countering Trump: Toward a Theory of Charismatic Counter-Roles. Social Forces. 97 (2): 921-944. 
Kantar. 2017. Voting Intention Poll Conducted 22 April-2 May 2017. http://www.tns-bmrb.co.uk/sites/ tns-bmrb/files/KPUK\%20Tables\%20and\%20Method\%20Note\%203.5.2017.pdf.

Kettle, M. 2017, May 11. The Problem with Labour's Manifesto isn't the Ideas, It's the Credibility. The Guardian.

Khomami, N. 2018, February 25. Anti-Corbyn Right-Wing Press Attacks 'Boost Momentum Support'. The Guardian.

Kogan, D. 2019. Protest and Power: The Battle for the Labour Party. London: Bloomsbury.

Kuenssberg, L. 2017a, May 19. Conservative Manifesto: Lack of Costings Leaves Blanks to be Filled. $B B C$.

Kuenssberg, L. 2017b, July 24. Anne McElvoy's Inside Story of the General Election. BBC.

Labour. 2017a. For The Many, Not The Few: The Labour Party Manifesto 2017. London: The Labour Party.

Labour. 2017b. Funding Britain's Future. London: The Labour Party.

Labour. 2020. The Work of the Labour Party's Governance and Legal Unit in Relation to Antisemitism, 2014-2019. London: The Labour Party.

Laclau, E., and C. Mouffe. 1985. Hegemony and Socialist Strategy: Towards a Radical Democratic Politics. London: Verso.

Levi-Strauss, C. 1967. Structural Anthropology. New York: Anchor Books.

Levi-Strauss, C. 1967. The Story of Asidwal. In The Structural Study of Myth and Totemism, ed. E. Leach, 1-48. London: Routledge.

Lo, M.-C., and Y. Fan. 2010. Hybrid Cultural Codes in Nonwestern Civil Society: Images of Women in Taiwan and Hong Kong. Sociological Theory. 28 (2): 167-192.

Mair, P. 2013. Ruling the Void: The Hollowing-out of Western Democracy. London: Verso.

Mason, R. 2017, April 19. Election will GIVE UK 'Strongest Hand' in Brexit Talks, Says Theresa May. The Guardian.

Mayhew, F. 2017. General election: Only five out of top 100 most-shared stories on social media were pro-Tory. Press Gazette. 12th June, 2017.

Mast, J. 2017. Legitimacy Troubles and the Performance of Power in the 2016 US Presidential Election. American Journal of Cultural Sociology. 3 (5): 460-80.

Mast, J.L. 2012. The Performative Presidency: Crisis and Resurrection During the Clinton Years. Cambridge: Cambridge University Press.

Mast, J.L., and J.C. Alexander, eds. 2019. Politics of Meaning/Meaning of Politics: Cultural Sociology of the 2016 U.S. Presidential Election. London: Palgrave.

McCarthy, J., and M.N. Zald. 1977. Resource Mobilization and Social Movements: A Partial Theory. American Journal of Sociology 82: 1212-1241.

McTague, T. 2015, August 12. Revealed: Corbyn 'Looked Forward' to Day Asteroid Wiped Out Humanity. Daily Mail.

Merrick, R. 2017, May 31. Theresa May Asked Why She Won't Debate Corbyn if She's Such a Strong Leader. Her Answer Says It All. The Independent.

Milne, S. 2017. General Election 2017 Strategy: Milne's PowerPoint presentation to Labour's National Executive Committee, 19th April, 2017. In Fall Out: A Year of Political Mayhem, ed. T. Shipman, 549-552. London: William Collins.

Momentum. 2015. 'About'. https://momentum.nationbuilder.com/about. Accessed 11 Jan 2021.

Morgan, M. 2020a. Why Meaning-Making Matters: The Case of the UK Government's COVID-19 Response. American Journal of Cultural Sociology. 8: 270-323.

Morgan, M. 2020b. A Cultural Sociology of Populism. International Journal of Politics, Culture and Society. https://doi.org/10.1007/s10767-020-09366-4.

Morgan, M., and P. Baert. 2015. Conflict in the Academy: A Study in the Sociology of Intellectuals. London: Palgrave Macmillan.

Mouffe, C. 2000. The Democratic Paradox. London: Verso.

MRC. 2015. Who Owns the UK Media? Media Reform Coalition Report.

Mudde, C., and C.R. Kaltwasser. 2017. Populism: A Very Short Introduction. Oxford: Oxford University Press.

Nielson, R.K. 2012. Ground Wars: Personalized Communication in Political Campaigns. Princeton NJ: Princeton University Press.

Nunns, A. 2018. The Candidate: Jeremy Corbyn's Improbable Path to Power. London: OR Books.

Ofcom. 2018. News Consumption in the UK: 2018. 
Pasha-Robinson, L. 2017, June 14. Election 2017: 61.5 per cent of Under-40s Voted for Labour, New Poll Finds. The Independent.

Perraudin, F. 2015. Labour Leadership Race: Tories Back Jeremy Corbyn in Bid to Damage Party, 16 June, 2015. The Guardian.

Pogrund, G., and P. Macguire. 2020. Left Out: The Inside Story of Labour Under Corbyn. London: Penguin Books.

Polletta, F. 1998. 'It Was like a Fever ...' Narrative and Identity in Social Protest. Social Problems 45 (2): $137-159$.

Polletta, F. 2006. It Was Like a Fever: Storytelling in Protest and Politics. Chicago, IL: University of Chicago Press.

Polletta, F., and J. Callahan. 2017. Deep Stories, Nostalgia Narratives, and Fake News: Storytelling in the Trump Era. American Journal of Cultural Sociology 5 (3): 392-408.

Poole, S. 2017, May 10. 'Strong and Stable Leadership!' Could Theresa May's Rhetorical Carpet-Bombing Backfire? The Guardian.

Prince, R. 2016. Comrade Corbyn: A Very Unlikely Coup: How Jeremy Corbyn Stormed to the Labour Leadership. London: Biteback Publishing.

Rambo, E., and E. Chan. 1990. Text, Structure, and Action in Cultural Sociology: A Commentary on 'Positive Objectivity' in Wuthnow and Archer. Theory and Society 19 (5): 635-648.

Reade, B. 2017, May 12. 'I'd Rather be Dragged Back to Jeremy Corbyn's 1970s than May's 1950s'. The Mirror.

Reed, I. 2013. Charismatic Performance: A Study of Bacon's Rebellion. American Journal of Cultural Sociology. 1: 254-287.

Reuters. 2017, June 18. UK's Hammond Says not Deaf to Voter Weariness on Spending Cuts. Reuters.

Richards, S. 2016. Leadership, Loyalty, and the Rise of Jeremy Corbyn. The Political Quarterly 87 (1): 12-17.

Ross, T., and T. McTague. 2017. Betting the House: The Inside Story of the 2017 Election. London: Biteback Publishing.

Salmon, C. 2010. Storytelling: Bewitching the Modern Mind. London: Verso.

Scott, J.C. 1977. The Moral Economy of the Peasant: Rebellion and Subsistence in Southeast Asia. New Haven: Yale University Press.

Scott, J.C. 1998. Seeing Like a State: How Certain Schemes to Improve the Human Condition have Failed. New Haven: Yale University Press.

Sharman, J. 2017. Reporters 'Locked in Room and Banned from Filming' on Theresa May factory visit. The Independent.

Shipman, T. 2017. Fall Out: A Year of Political Mayhem. London: William Collins.

Simmel, G. 1957. Fashion. American Journal of Sociology 62 (6): 541-558.

Skinner, G., and R. Mortimore. 2017. How Britain Voted in the 2017 Election. Ipso Mori, https://www. ipsos.com/ipsos-mori/en-uk/how-britain-voted-2017-election.

Smith, M. 2017. Jeremy Corbyn is on the Right Side of Public Opinion on Foreign Policy: Except for the Falklands. YouGov.

Smith, P. 1994. The Semiotic Foundations of Media Narratives: Saddam and Nasser in the American Mass Media. Journal of Narrative and Life History. 4 (1-2): 89-118.

Smith, P. 2005. Why War? The Cultural Logic of Iraq, the Gulf War, and Suez. Chicago: University of Chicago Press.

Snow, D.A. 2013. Social Movements. In The Blackwell-Wiley Encyclopaedia of Social and Political Movements. Oxford: Blackwell.

Stambolieva, E. 2017. Detecting Online Abuse Against Women MPs on Twitter. Amnesty International.

Steel, M. 2017, May 11. Labour's Manifesto Proves They're Stuck in the 1970s, Unlike the Modern Tories Who Want Fox-Hunting Back, The Independent.

Sterrett, D., Malato, D., Benz, J., Kantor, L., Tompson, T., Rosenstiel, T., Sonderman J, \& Loker, K. 2018. Who Shared It? How Americans Decide whatNews to Trust on Social Media, Norc Working Paper Series, WP-2018-001, 1-24.

Stewart, H. 2018, February 5. Theresa May Calls ABUSE in Public Life 'A Threat to Democracy'. The Guardian.

Stewart, H., and J. Elgot. 2016, December 15. Labour Plans Jeremy Corbyn Relaunch to Ride Anti-Establishment Wave. The Guardian.

Stone, J. 2016, January 26. Liz Kendall says She Lost the Labour Leadership Election Because She was the 'Eat Your Greens' Candidate, The Independent. 
Stone, J. 2017, April 18. Here are All the Times Theresa May Said There Would be no Election. The Independent.

Swidler, A. 1986. Culture in Action: Symbols and Strategies. American Sociological Review 51 (2): 273-286.

Syal, R. 2018, August 22. Labour Raised $£ 10 \mathrm{~m}$ More than Tories Last Year, Says Watchdog. The Guardian.

The Economist. 2017, May 17. The Labour Party Raises the Bar for Electoral Suicide Notes - Manifesto Madness. The Economist.

Thompson, E.P. 1963. The Making of the English Working Class. London: Penguin.

Thompson, E.P. 1971. The Moral Economy of the English Crowd in the Eighteenth Century. Past \& Present 50 (1): 76-136.

Thompson, E.P. 1978. Poverty of Theory: An Orrery of Errors. London: Merlin Press.

Thorpe, A. 2015. A History of the British Labour Party. London: Red Globe Press.

Todd, S. 2014. The People: The Rise and Fall of the Working Class 1910-2010. London: John Murray.

Tonge, J., C. Leston-Bandeira, and S. Wilks-Heeg, eds. 2018. Britain Votes 2017. Oxford: Oxford University Press.

Travis, A. 2017, May 11. 1983 v 2017: HOW LABOUR'S MANIFESTOS COMPARE. The Guardian.

Turner, V. 1966. The Ritual Process: Structure and Anti-Structure. Ithaca NY: Cornell University Press.

Turner, V. 1969. The Ritual Process: Structure and Anti-Structure. Chicago: Aldine Publishing Company.

Turner, V. 1974. Dramas, Fields, and Metaphors: Symbolic Actionin Human Society. Ithaca: Cornell University Press.

Wagner-Pacifici, R. 1986. The Moro Morality Play: Terrorism as Social Drama. Chicago: Chicago University Press.

Walsh, M. 2017, November 10. Understanding Labour's Ingenious Campaign Strategy on Facebook. LSE British Politics \& Policy Blog. https://blogs.lse.ac.uk/politicsandpolicy/explaining-labours-faceb ook-success/.

Weber, M. [1922] 1978. Economy and Society. Los Angeles: University of California Press.

Wheeler, B. 2017, May 23. The Jeremy Corbyn Story. BBC. https://www.bbc.com/news/election-201739807055.

Williams, R. 1958. Culture \& Society: 1780-1950. London: Chatto \& Windus.

Woodly, D.R. 2015. The Politics of Common Sense: How Social Movements Use Public Discourse to Change Politics and Win Acceptance. New York: Oxford University Press.

Wring, D., R. Mortimore, and S. Atkinson, eds. 2018. Political Communication in Britain: Campaigning, Media and Polling in the 2017 General Election. New York: Palgrave Macmillan.

YouGov. 2017a. Political Tracker: Government Cuts. https://d25d2506sfb94s.cloudfront.net/cumulus_ uploads/document/xjt2iq1a7v/YG\%20trackers\%20-\%20Government\%20Cuts.pdf.

YouGov. 2017b. Fieldwork 9-13 June. https://d25d2506sfb94s.cloudfront.net/cumulus_uploads/docum ent/smo1w49ph1/InternalResults_170613_2017Election_Demographics_W.pdf.

Young, L. 2018. Rise: How Jeremy Corbyn Inspired the Young to Create a New Socialism. London: Simon and Schuster.

Zeffman, H. 2017, April 20. Manifesto has Echoes of 'Longest Suicide Note in History'. The Times.

Publisher's Note Springer Nature remains neutral with regard to jurisdictional claims in published maps and institutional affiliations.

Marcus Morgan is a sociologist at the University of Bristol, UK. His current research examines how culture shapes political life. His latest articles include 'A Cultural Sociology of Populism' (2020), and 'Why meaning-making matters: the case of the UK Government's COVID-19 response' (2020). He is also the author of Pragmatic Humanism: On the Nature and Value of Sociological Knowledge (Routledge, 2016), and co-author of Conflict in the Academy: A Study in the Sociology of Intellectuals (Palgrave, 2015). He is co-editor of the BSA/SAGE journal, Cultural Sociology. 